\title{
Adapting Śaiva Tantric Initiation for Exoteric Circles: The Lokadharmiṇ̄ Dīkșā and Its History in Early Medieval Sources
}

\author{
Nina Mirnig
}

A consistent concern in the study of early Śaivism is to understand the scope of the clientele texts were written for, and how representative this literature was of practices on the ground at given times. The methodological limitations we face in exploring this largely prescriptive body of literature in relation to actual practice are notorious. Yet, in his seminal works on Śaiva religious history, Alexis Sanderson developed groundbreaking insights into the socioreligious and political landscape in which the surviving texts were produced, reconstructing processes that led to the dominant position of Saivism in the medieval Indic world. Thanks to his pioneering research, and that of other scholars who have taken up the subject in the wake of his work, our understanding of the relative chronology of Śaiva scriptures and medieval authors has also greatly improved. ${ }^{1}$ This increasingly enables us to investigate these materials historically, and thus to pursue questions of a socio-historical nature, which are at the heart of Sanderson's work. In his own words (Sanderson 2005, 230),

$[\ldots]$ it is possible, I would say necessary, to read the literature and inscriptions with the sort of questions in mind that a social historian would wish to ask.

For this felicitation volume, the present article is intended as a small contribution of this kind, applying a social-historical approach to a certain form of Śaiva initiation, namely the lokadharmiṇi dīkșā. In essence, this denotes a form of initiation that is compatible with maintaining one's socio-religious and ritual obligations in society-the lokadharma.

1 See, e.g., Goodall 1997, xxxvi-lxxvi, and the preface and introduction to Goodall 2004, as well as Sanderson 2001 and 2014. 
Scholars familiar with tantric traditions know well that initiation $(d \bar{l} k s ̦ \bar{a})$ is one of the core tantric rituals. As Goodall explains, tantric initiation was novel and different from earlier Indic forms of religious initiation, being not only "a preparation for a particular religious undertaking, but ... also a transformative rite that purifies the soul." ${ }^{2}$ This purification is achieved through an innovative ritual technology, using the power of mantras to destroy an individual's karmas and connected rebirths at all reality levels (tattvas). This enables the Śaiva Guru to free the bound soul of all ties, and to guide the candidate to a cosmic level where he can either realize liberation through union with the highest form of Śiva, if he is a liberation seeker (mumukșu), or attain divine powers, if he is a seeker of supernatural powers and enjoyments (bubhukșu). As such, tantric initiation confers spiritual benefits to the candidate a priori to his practice. It is thus arguably the most powerful tantric rite, designed in principle for practitioners who intend to devote their lives to the religion, as was probably the case in its original setting of esoteric, probably ascetic, circles.

At the same time, we know from history that tantric Śaivism did not remain confined to the margins of society, but emerged as a religious movement which successfully interfaced with the mainstream, and gradually came to dominate the religious and socio-political discourse of the early medieval Indic world. ${ }^{3}$ As one would expect, this development is reflected in ritual and in changes to the constitution of the initiatory community, which by then encompassed not only ascetic practitioners fully devoted to Śaiva religious practice, but also brahmanical householders. The increasing engagement with the mainstream led to the creation of exoteric forms of initiation, including versions that would confer spiritual benefits without requiring the candidate to adopt a purely Śaiva ritual lifestyle. The most well-known example is the nirbijja dìkșa ("initiation without the seed [of having to perform post-initiatory rites]"), which offers the candidate the highest soteriological goal of ultimate liberation at the time of death. However, according to the scriptures, such an initiation was only granted in special cases, namely when the candidates were considered unable to perform any kind of post-initiatory practice for special reasons. The list of such people classically comprises the king, but also the old, the young, the sick, and women. ${ }^{4}$

2 See Goodall's entry on dīkșā in Tāntrikābhidhānakośa, vol. III.

3 See, e.g., Sanderson 2009.

4 See, e.g., Svacchanda, 4.88, as quoted by Goodall in his entry on nirbüjadīkșā in Tāntrikābhidhānakośa, vol. III. 
The other, lesser-known form of exoteric initiation is the lokadharminī dìkșā, which forms the subject of this paper. This term translates as "the initiation which contains/adheres to the lokadharma," the lokadharma denoting the sphere of observance that Śaiva sources consistently define as the exoteric religion of śruti and smrti, that is to say the domain of the brahmanical householder. ${ }^{5}$ Unlike the nirb $\ddot{j} \bar{a}$, access to the lokadharmini initiation is not limited to specific groups, and in its original context, the initiation is mainly benefitoriented: a lokadharmi initiate is said to pursue mundane spiritual goals before attaining some kind of divine status. He does so by means of the merit procured through lay worship, and not through Śaiva rites that require the propitiation of mantras. This seemingly antithetical initiatory category is little discussed by Śaiva authors, probably precisely because of the doctrinal implications of such an initiation, which foregrounds a level of practice and spiritual goals that Śaivas claim to surpass. In the course of time, the lokadharminī initiation underwent several shifts in application. These developments are deeply entangled with the complex history of the system of initiatory categories, which was subject to processes of division and reassignment reflecting local and historical circumstances. A historical investigation into this form of exoteric Śaiva initiation therefore touches upon the larger issue of how tantric initiatory communities related to the brahmanical mainstream, at various stages, after their emergence from esoteric ascetic circles.

The first part of the paper investigates the lokadharmini in its original setting, as an initiation for Sādhakas, first by surveying the available sources and then by contextualizing them in the socio-religious setting of tantric Śaivism's early stages. The second part will examine how this category of exoteric bubhu$k s ̦ u$ initiation is subsequently re-assigned to the sphere of the mumukșu, thus becoming integrated into the Śaiva soteriological path, especially in the Jayadrathayamala. The third section looks into the usage of the lokadharmi category in the ritual manuals of the 11th-13th centuries, particularly sources from the South, tracing how in some works, notably the Jñānaratnāvalī, there is another shift in usage: the lokadharminī dīkșā comes to denote a regular Śaiva initiation for the householder, as opposed to the ascetic, who receives a sivadharmini $d \bar{\imath} k s \underline{a}$. The final section reflects upon how the initiatory category of the lokadharminī fits within the larger context of tantric Śaivism's development in medieval India.

5 For an example, see Kșemarāja ad Svacchanda 4.85: lokamārgah śrutisṃrtyācāraḥ ..., also quoted in note 10. 


\section{The Original lokadharmiṇi dīkșā as a Form of Sādhaka Initiation: Sources and Mechanics}

The earliest sources that mention a lokadharmiṇi dīkșa- -always as the counterpart of the śivadharminī dīkșa- -feature it as a form of Sādhaka initiation ${ }^{6}$ in the domain of the bubhukșu, i.e. the seeker of power and enjoyment, as opposed to the liberation-seeker (mumukșu). The first extant text to feature the lokadharmini is the Svacchanda. In its fourth chapter, dedicated in its entirety to initiation, the text gives an overview of all the initiation categories, dividing the initiatory community into mumukșus and bubhukșus. The former may receive either a sabījā or nirbijjā initiation, and the latter a śivadharmiṇi or lokadharmin̄i initiation. ${ }^{7}$ Of these, the śivadharmī Sādhaka is the Śaiva Sādhaka proper, who through initiation gains the ability to propitiate Śaiva mantras in order to attain benefits and supernatural powers, while the lokadharmì Sādhaka is his exoteric counterpart, seeking enjoyments and spiritual benefits through mundane religious acts rather than mantras:

The Sādhaka is of two kinds. On the one hand, there is the śivadharmī, for whom the cosmic path is purified by Śaiva mantras and who is yoked to [particular] mantras that are to be mastered; he is knowledgeable, consecrated [to office], and devoted to the propitiation of mantras. This Saiva Sādhaka is capable [of mastering] the threefold supernatural powers. ${ }^{8}$ The second [kind of Sādhaka] adheres to the mundane path and

6 Brunner, in her 1975 paper dedicated to the figure of the Sādhaka, also outlines many of the general features of the Śaiva Sādhaka's initiation and practice thereafter. She does, however, not treat the lokadharmin̄i kind of initiation at length.

7 Svacchandatantra 4. 79b-81b: atha dīkșādhvaśuddhyartham bhuktimuktiphalārthinām || vidhānam ucyate sūkșmam pāśavicchittikārakam | guruh saṃprcchate sișyam dvividham phalakānikșinam || phalam ākāìkșase yādṛk tādṛk sādhanam ārabhe|, "Next there is the initiation for the purpose of the purification of the cosmic path (adhvan) for those who seek the fruit of [either] enjoyment or liberation. The subtle method that causes the cutting of the bonds is explained. The Guru asks the candidate seeking benefits [about] the two-fold [option]. Whatever fruit he desires, accordingly he should start the propitiation of Mantras."

8 This may be a reference to the old classification of siddhis into three kinds, which goes back to early sources such as the Niśvāsa and Buddhist Kriyātantras, as Goodall (2014, 16 and 8o82) discusses. Thus, in the Niśvāsa Guhyasūtra three levels of siddhi can be attained after preparing some potion. Which kind of siddhi has been obtained can be deduced from the manifestation of heat, if the power is to cover great distances on foot, the manifestation of smoke if he is to have the power to disappear, and the manifestation of flames if he is to have the power to walk through the sky (Goodall 2013, 81). For more on siddhi-practices in Tantric Śaivism, see Vasudeva 2012. 
is devoted to the performance of good and meritorious works (iștāpu tavidhau); desiring the fruits produced by [his] karma, he abides solely [devoted to] meritorious [karma], free of the unmeritorious. [The Guru] should always perform the destruction of the unmeritorious portion [of the candidate's karma] with mantras. ${ }^{9}$

Kșemarāja, in his commentary, further specifies that meritorious acts in the case of the lokadharmi consist of bathing at sacred places, providing food and building wells, tanks and monasteries..$^{10}$ These are precisely the kinds of religious activity that we would expect of an ordinary lay worshipper. As we see in this passage, what the lokadharmini initiation does is to enhance the initiate's spiritual benefits by destroying bad karma connected to all reality levels, leaving only good karma and its positive outcomes in place.

This function of the lokadharminī dìkșa is reiterated later in the chapter, when the text explains how the two kinds of bubhukșu initiations differ from that of the mumukșu. These differences concern two points: ${ }^{11}$ firstly, the portion of karma that is purified and thus removed for the candidate; and second, the cosmic level at which the candidate is united with the respective deity upon initiation's conclusion:

Next, he should then bring about destruction of the past and future karma for the liberation-seeker (mumukșu), because of his indifference [to the world]. He should not purify the one [part of karma] that is the prārabdha [karma], [which fuels his present existence]. But for the Sādhaka, he should purify [only] one [part of the] past karma for the purpose of power, ${ }^{12}$ and having manifested the past and future karma together (ekastham), he should initiate [the candidate]. This is the sivadharmini dīkșā. The

Svacchanda 4.83-86b: sādhako dvividhah tatra śivadharmy ekatah sthitah | śivamantraviśuddhādhvā sādhyamantraniyojitah ||jñānavāñ cābhisisiktaś ca mantrārādhanatatparah | trividhāyāh tu siddher vai so 'trārhah śivasādhakaḥ || dvitīyo lokamārgastha ișțāpūrtavidhau ratah | karmakṛt phalam ākāinkșañ śubhaikastho 'subhojjhitah || tasya kāryam sadā mantrair aśubhāmiśavināśanam|.

10 Kșemarāja ad Svacchanda 4.85: lokamārgah śrutismrtyāāāraḥ. iștam tīrthasnānānnadānādi. pürtam kūpatadāankamațhādi, "The mundane path is the observance according to śruti and smrti. The sacred rites (iștam) [consist of] such actions as bathing at a sacred site and giving away food. The meritorious acts ( $p \bar{u} r t a)$ are [the donations and setting up of] such things as wells, tanks and monasteries for ascetics."

11 See also, Brunner 1975, 417-420.

12 See pp. $254 \mathrm{ff}$. for a discussion of this problematic passage, here italicized. 
other form [of bubhukșu initiation] is the lokadharmini, which destroys both past and future demerit. That lokadharmini $\bar{\imath}$ [diksșā] is known to exclude the obligation to propitiate mantras [by means of purvaseva etc.]. However, when the current body breaks, [the candidate] experiences [the series of eight supernatural natural powers] starting with becoming very small (anima $\bar{a}$ ). Having experienced [these] enjoyments he moves upwards to whichever [cosmic level] the Guru has joined him [by yojanikā]. Whether this is at the sakala or nișkala level [of Siva] depends on [the preference of] the candidate and Guru. ${ }^{13}$

Thus, we learn that the lokadharmi candidate can be united with any deity of any cosmic level at the end of the procedure, and could even choose to be united with the highest, nișkala form of Śiva, a form of union synonymous with the state of ultimate liberation. In addition, while the lokadharmi initiate cannot propitiate Śaiva mantras, unlike the Sādhaka, he is nevertheless granted supernatural powers, which are usually said to result from mantra practice; the difference is that he experiences these powers after death.

Regarding the śivadharmiṇi dì $s s ̣ \bar{a}$, we note that there is some difficulty interpreting how karma is held to be eliminated at this point. As evident from the translation, the problematic phrase is 142ab, sādhakasya tu bhütyartham prākkarmaikam tu śodhayet; this is supposed to define the difference in procedure from the nirvānadīkșā of the mumukșu, for whom only prārabdha karma, the karma that fuels the current life, is to be preserved. ${ }^{14}$ Looking at the different treatments of this phrase, we find that commentators disagree on whether or not any additional karmic bonds are excluded from purification-and in effect, whether the dīkșa of the Sādhaka is very close to that of the mumukșu Putraka or not. Kșemarāja, in his commentary, wants to see a clear difference, and interprets this passage to indicate that two kinds of karma are excluded from purification, in case of the Sādhaka, namely (1) the karma that is necessary for the attainment of supernatural powers (i.e. bhütyartham ), without

13 Svacchanda 4.141-145: prākkarmabhāvikasyātha abhāvam bhāvayet tadā | mumukșor nirapekșatvāt prārabdhr ekạ̣ na śodhayet || sādhakasya tu bhütyarthaṃ prākkarmaikaṃ tu śodhayet | prākkarmāgāmi caikastham bhāvayitvā ca dīkșayet || śivadharminy asau dīkșā lokadharminy ato 'nyathā | prāktanāgamikasyāpi adharmakșayakārin̄ī || lokadharminyy asau jñeyā mantrārādhanavarjitā | prārabdhadehabhede tu bhừkte sa hy aṇimādikān || bhogān bhuktvā vrajed ūrdhvam guruṇā yatra yojitạ̣| sakale nișkale vāpi sissyācāryavaśād bhaved $\|$.

14 For the locus classicus regarding the mechanics of prārabdha karma, see Kirana 6.20-21, edited and translated in Goodall 1998. 
making explicit what that means, ${ }^{15}$ and (2) the good portion of the prārabdha karma, which ensures the success of the siddhi practice by preventing its being blocked by bad karma. ${ }^{16}$ On the other hand, Abhinavagupta, when adopting this passage in his Tantrāloka, as discussed below, drops pādas $142 \mathrm{~cd}$ and rephrases 142ab as prākkarmettham tu śodhayet, "He should purify the past karma in the same way [as in the case for the mumukșu]" - thus indicating that for him, the procedure for the Sādhaka is exactly the same as for the mumukșu Putraka, except that the prärabdha karma is directed towards supernatural powers rather than liberation. In his commentary on this passage, Jayaratha, in turn, criticizes Kșemarāja's reading of ekam instead of ittham, undermining his understanding that the bad portion of the prärabdha karma is destroyed, instead saying that neither is it possible to remove any part of the prärabdha karma, since this fuels the current life force, nor does this interpretation have scriptural support. ${ }^{17}$ At the same time, he remains silent about the fact that the text teaches the removal of only the bad karma in case of the lokadharmini dīkșa..$^{18}$

15 Kṣemarāja ad Svacchanda 4.142a (sādhakasya tu bhütyarthaṃ): bhütiproyojanam bhāvimantrārādhanarüpam yat tad api na śodhayed ity arthah, "He should not purify the [portion of karma] which is for the future propitiation of mantras for the purpose of supernatural powers; this is the meaning."

16 Kșemarāja ad Svacchanda 4.142b (prākkarmaikam tu śodhayet): bhūtyarthād yat prāg dehārambhi śubhāśubham tata ekam aśubham evāsya śodhayet, evaṃ hi nirvighnaṃ bhogasiddhir bhavati || yat tu janmāntarasaṃcitam śubhāśubham yac cāsmiñ janmani karisyati, tat sarvam uktanītyā mantrārādhanavarjam asya putrakavac chodhyam evety āha, "For the purpose of supernatural powers, from the past pure and impure [karma] that maintains the [current] body (i.e. the prārabdha karma) he should only purify the impure [portion] for him, for in this way (evam) the achievement of enjoyment comes about without any obstacles. As for the pure and impure [karma] that is accumulated in other [past] births and which he will do in a [future] birth, all those should be purified for him according to the proclaimed procedure, like in the case of the Putraka, apart from [those karmas for] the propitiation of mantras (mantrārādhanavarjam). Therefore he said, [prākkarmāgāmi caikastham bhāvayitvā ca dīkșayet (Svacchanda 4.142cd)]."

17 Jayaratha ad Tantrāloka 15.28: sādhakasya ca ittham eva karmaśodhanam, kim tu tat bhütyartham, tasya hi bhogaunmukhyāt tadvāsanābhedāt phalabheda iti pratijñāto 'pi artho nirvāhitah |yad uktam "sādhakasya tu bhūrtyartham prākkarmettham tu śodhayet | prākkarmāgāmi (corr. Hatley; prākkarmagāmi Ed.) caikastham bhāvayitvā tu dīkșayet” iti. atra ca udyotakrtāyad ittham iti apāsya ekam iti pațhitvā dehārambhiśubhāśubhakarmamadhyād ekam aśubham api asya śodhayed iti vyākhyātam, tad upekșyam ārabdhakāryadehārambhikarmocchedāśakyatvasya prāgupapāditatvāt kva cid apy evam anāmnātatvāc ca.

18 A similar problem of interpretation also occurs in the passage of the Mrgendra, which outlines the superior and the inferior bhautiki dīkșa, the former being the śivadharminī and the latter the lokadharmini. This passage appears to say that for the superior kind, i.e. the śivadharmin̄i, along with the prārabdha karma some undefined additional karma is 
Another early source which distinguishes between the śivadharmini and lokadharminī dīkșa is the Mrgendra, which was composed after the Svaccha$n d a$. This scripture maintains the same basic set of categories and organization of initiatory groups, even though it uses slightly different terminology. Thus, instead of referring to initiations for the mumukșu and the bubhukșu, the Mrgendra uses the terms naișthiki and bhautikī, ${ }^{19}$ the former of which is

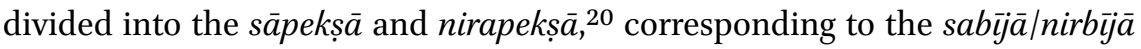
distinction, and the latter again into śivadharmin̄i and lokadharmin̄i, for which we find the following description:

preserved for the success of the siddhi practice (śaivasādhanasādhyena), perhaps similar to Kșemarāja's bhütyartham category. Mrgendra 8.1146-148: evam eva kriyāyogäd bhautiky api parāparā | kiṃ tu dehāviyogārtham prārabdhaṃ karma dehinạ̣ || śaivasādhanasādhyena saṃdhāya paripālayet | sānubandham dahed anyad dīpte dīkșāhutāśane || kașțākaștapadāntasthe sādhake pañcakeśvare | yogo 'syātmikadeśinyām anyasyām iștavigrahe || (for a translation, see Brunner 1985, 258). However, Bhațta Nārāyaṇakaṇțha, commenting on this passage, is against such an interpretation, and rather awkwardly interprets śaivasādhanasādhyena to refer to the post-initiatory discipline that the Sādhaka is to carry out, which would seem odd given that such post-initiatory practice is also to be carried out by the mumukșu: ... prärabdham karma prārabdhakāryam dehinah jantoḥ dehāviyog $\bar{a}-$ rtham śarīrapātasaṃrakșārthaṃ śaivasādhanasādhyena samayācārapālanena saṃdhāya samyojya paripālayet rakșayet. (For a translation, see Brunner 1985, 286).

19 That the terms bhautiki and naitșthiki correspond at this point to the initiations for the bubhukșu and mumukșu respectively, is suggested by the commentary of Nārāyanakaṇțha (ad Mrgendra, Kriyāpāda 2: nișțā kaivalyam. te bhütinișțhe prayojanaṃ yayos te tathā. bhautikībhütikāmasya. nișțārthino naișțhikī nairvāṇikity arthah ), which also Brunner follows in her translation, translating bhautiki as "donneuse de jouissance" and naișthiki as "donneuse de liberation" (Brunner 1985, 199). Further, from later passages it is clear that the bhautiki is equated with the Sādhaka; e.g. in Mrgendra, Caryāpäda 11, where the lokadharmin̄i is even referred to as a Sādhaka. As such, this division of the Mrgendra would reproduce the same structure as we found it in the Svacchanda; but internally we have to note that the category of the bhautiki and the naișthikī, if taken in this manner, don't overlap with what in the Cäryapāda of the Mrgendra is described as bhautikavratins and naișthikavratins, as Brunner (1985, 347, note 2$)$ already points out. Thus, here, the bhautikavratin, i.e. one who has a temporary vrata, and the naișthikavratin, who has a permanent vrata, are both opposed to those who have no vrata at all (avrata), a category which, in turn, includes the lokadharmī sādhaka featuring under the bhautikì dīkșā. However, it may be that the Mrgendra is simply not entirely consistent. Interpretative problems appear also in other places regarding the definitions and procedures for the śivadharmin̄i and lokadharmin̄i, and similarly, perhaps confusion also remains on the bhautiki and naișthiki distinction. Goodall also draws attention to the difficulties in interpreting the terms naitșthika and bhautika in his entry on the term naișțika in Tāntrikābhidhānakośa, vol. III.

20 However, note that in her English summary it seems that Brunner $(1985,481-482)$ applies the divisions of sāpekșā and nirapekșā to both the naișthiki and bhautikī. 
The sivadharmini [initiation] is the root of success for the fruits of the Saiva religion for the individual soul. There is another [kind of sivadharmini $]$ taught without the destruction of the body, up until the dissolution of the world. ${ }^{21}$ The remaining one is taught to be the lokadharmini, for the purpose of [attaining the eightfold supernatural powers] starting with anima after the current life, after all the bad portions [of karma] were destroyed at all reality levels. ${ }^{22}$

While the description of the śivadharmin̄i initiation differs somewhat, implying that there are two levels of Śaiva Sādhaka, ${ }^{23}$ the explanation of the lokadharmini resonates much with what we found in the Svacchanda, namely that all bad karma is destroyed and the initiate attains supernatural powers after death. Regarding the end point of union for the lokadharmi candidate, the Mrgendra offers a choice similar to that of the Svacchanda, namely that the candidate is either lifted up to the cosmic level of his choice and absorbs the applicable deity's divine powers, or that he is united with the highest form of Śiva, for liberation:

Having lifted up the lokadharmi to [the cosmic level of] the deity he desires, he should cause [this deity's] qualities to be present in the candidate, or, for those desirous of liberation, [join him] in Siva. He should establish the [regent] who is at the top of the [respective] path, ${ }^{24}$ together with his powers, recite the om at the end of the mantra, and then join [him with the deity], while remaining untouched by unmeritorious $[\text { karma }]^{25}$

21 See below, note 23.

22 Mrgendra, Kriyāpāda 8.6-7: śivadharminy anor mūlaṃ śivadharmaphalaśriyah | hitetarā vinā bhañgam tanor à vilayād bhuvām || bhogabhūmișu sarvāsu duṣkrtāṃśe hate sati| dehottarāṇimādyartham śișteșțā lokadharmiṇī||

23 The definition of the śivadharmini appears more general here, in comparison to the Svacchanda, since the śivadharmin̄i bhautikì initiation is simply said to confer the fruits rooted in the Śaiva religion, presumably through the propitiation of Śaiva mantras. In addition, the Mrgendra also teaches a special version of the sivadharmini, in which the candidate attains the ability to keep his body until the end of dissolution, the form of the sivadharmī that Bhața Nārāyaṇakaṇțha declares to be the superior one (see Nārāyaṇakaṇțha ad Mrgendra 8.6b: itarā dvitīya śivadharminy eva tanoḥ bhañgam vinā hitā vihitā śreyas sādhikā.).

24 I am following Brunner's interpretation $(1985,287)$ of the problematic phrase placed here in italics.

25 Mrgendra, Kriyāāāda 8.149-150: lokadharminam āropya mate bhuvanabhartari | taddharmāpādanam kuryāc chive vā muktikān̄kșin̄ām || yasya yo 'dhvā tadantas tam upasthāpya satadbalam | mantrānte tāram uccārya yojayet kaștam asprśān || . 
However, the Mrgendra goes even further than the Svacchanda and makes explicit that this procedure can also be applied in case a candidate wishes to be united with a non-Śaiva brahmanical deity:

In exactly the same way (evam eva), [the Guru] may guide a devotee to union [with a deity such as] Ambikā, Sūrya, Smara, Viṣṇu or Brahmā, after having purified that path [up to the cosmic level of the desired deity] [of all bad karma]. And the same procedure (evam eva hi) [is applicable] for any other deity that is on the path [that the devotee wishes to be united with]. ${ }^{26}$

As for the mode of religious practice of the lokadharmī, we learn in the Cary $\bar{a}$ pāda of the Mrgendra that the lokadharmi is avrata, ${ }^{27}$ presumably referring to

26 Mrgendra, Kriyāpāda 8.151-152b: evam evāmbikāsūryasmaraviṣnuprajāṣjā̄m | sāyujyam bhaktimān neyas tad adhvani viśodhite \| mārgasthānām pareșām ca devānām evam eva hi|.

27 Mrgendra, Caryāpāda 11: sādhako lokadharmī yah putrakah snātako grhī | samaȳ̄ prāggṛhasthaś ca śaivāh syur vratavarjitāh \|, "The lokadharmī Sādhaka, a Putraka who is a married householder, a Samayin and someone who was previously a householder [and had become a saṃnyāsin ] are Śaivas without vratas." (I follow Brunner $(1985,349)$ here in separating the Samayin and prāggrhastha, i.e. one who was previously a householder, as two kinds of initiates intended here; Kșemarāja also interprets the passage thus. However, as Brunner already points out, this category makes little sense in the present context.) See Kșemarāja ad loc.: sādhakasya śivadharmilaukikadharmibhedād dvaividhye sati lokadharmì yah sādhakah, putrakah, tathā snātako gṛhīgrhasthatve sati snātah, samaȳ̄, prāggrhasthah pūrvam gṛhasthaś cety ete vratavarjitā jñeyāḥ| prāggrhasthaś ca ity uttarakālam gārhasthyatyāgāpekșayā | yatah sambhavanti kecana ājōvanam ujjhitagrhhāvasthitayah | tadvailakșanyārtham prāggrhasthagrahanam \|. As Brunner (1985, 350, note 5) argues, vrata appears here to refer to a Śaiva observance with mantras, as in the Svacchanda, perhaps combined with an abstinent ascetic lifestyle, rather than to the performance of a Śaiva post-initiatory discipline as a whole; this is indicated by the fact that the lokadharmi is mentioned here next to the Putraka who is a snataka and thus married, the Putraka who is a head of the household, the Samayin, and someone who is the head of the household, though this last category is dubious. In any case, of those we can expect that at least the Samayin and the married Putraka-unless he received a nirbijā initiationwould have had to comply with the samayas. On the other hand, the other interpretation of vrata above would fit for all those cases, since such an ascetic lifestyle would not be appropriate for the married Putraka, and the Samayin would perhaps not be considered able yet to do so given his neophyte status. Nevertheless, there appears also to be the possibility of becoming a bhautikavratin with a temporary vrata, in which case the practitioner is instructed to reject the paraphernalia he received for the practice and offer them back to the deity after the successful outcome of his vrata (see Mrgendra, Caryāpāda 9b$10)$. 
his not being able to perform religious observances involving propitiation of mantras, just as we have seen in the Svacchanda.

Aside from the Svacchanda and the Mrgendra, there is one more scripture that features the lokadharmiṇi as a type of Sādhaka initiation, namely the Tantrasadbhāva. However, this scripture does not provide any details con-

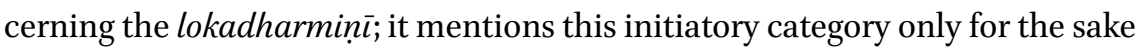
of completeness while introducing the sivadharminī dīkșā, here also called vidyā $\bar{i} k s \bar{a}^{, 28}$ as the initiation undertaken by the Śaiva Sādhaka before receiving consecration. ${ }^{29}$

The lokadharmiṇi /śivadharminī distinction between Sādhaka initiations is carried over into Abhinavagupta's early-11th-century Tanträloka, ${ }^{30}$ since Abhinavagupta incorporates the Svacchanda passage into his work, somewhat mod-

28 Cf. the vidyādīkșā in the Niśvāsa, Goodall et al. 2015, 280-282.

29 Tantrasadbhāva $9 \cdot 516 \mathrm{~cd}-522$ (the variants are recorded from the etext of Dyczkowski; emendations and conjectures are my own): sa guruh śivatulyas tu *sivadharmaphalapradaḥ (em.; śivadhāmaphalapradah Ed.) ||516|| śāntyaṃte bhūtidīkșā tu sadāśivaphalātmikā | *sivadharmī (kh; śivadharmo $\mathrm{K}, \mathrm{g}$ ) tu sā jñeyā lokadharmī matānyathā ||517|| śivadharmī tu yā dīkṣā sādhakānām prakīrtitāh | teșām kuryābhișekaṃ tu sādhakatve (kh, $\mathrm{g}$; *sādhakam *? K) niyojayet $\left\|_{518}\right\|$ sādhakasyābhișeko 'yam vidyādīkșād anantaram | †vidyādīkșā bhavet sā tu vāsanā̈bhedatah (corr.; -bhedata mss.) sthitā ||519|| na karmabhede vidyeta *sarvo 'syādhvani (conj.; sarvāsyādhvani Ed.) saṃsthitạ $\mid$ krtāni yāni karmāni sarvāṇy adhva* gatāni (K, kh; -sarvānya- g) tu $\left\|_{520}\right\|$ tāni saṃśodhya (K, g; sa -- kh) vidhivat kalāpañcasthitāni vai $\mid$ yojanyāvasare bhedạ̣ vijñātam (conj. Hatley; bhedo vijñānam mss.) sādhakasya tu ||521|| prārabdhakarma paśvarthe tam ekastham tu bhāvayet | śivam uccārya sakalam sadāśivatanau (K, kh; sadāsiva -- g) nyaset ||522||, "That Guru is equal to Śiva, bestowing the fruits of the Śaiva dharma. The bhütidīkșā contains the fruits of Sadāśiva at the end of the Śānti [level]. This [initiation] is known as the Śivadharmī; the other is called the Lokadharmī. The Sivadharmī is known to be the initiation for Sādhakas. For them [the Guru] should perform consecration, and unite them with the state of being Sādhakas (sādhakatve). The consecration for the Sādhaka [should be performed] after the vidyādīkșā. †The vidyādīkșa is based upon a difference in intention (vāsanā); one should not understand it on the basis of difference in action (karma). Everything is established on the path: all actions which have been performed, associated with [various levels of] the cosmic course [of tattvas] [and] established on/with the five kalās, should be duly purified. $\dagger$ The difference [in procedure] for the Sādhaka is known to be at the time of union [with the deity]: he should manifest together (ekastham) the prärabdha karma for the sake of the bound soul, pronounce the mantra of Śiva in its sakala form, and place [the consciousness] into the body of Sadāśiva."

$30 \quad$ Tantrāloka 15.23c-24b: sādhako dvividhah śaivadharmā lokojjhitasthitih || lokadharmīphalākāṃkṣi śubhasthaś cāśubhojjhitah |, "There are two types of Sādhakas. The one following the Śaiva dharma [i.e. Śivadharmī] is free of mundane [observances]. The lokadharmi Sādhaka is desirous of fruits, rooted in meritorious [actions] and free of impure [actions]." 
ified. ${ }^{31}$ However, Abhinavagupta does not deal with the śivadharmī/lokadharmī Sādhaka distinction beyond quoting this passage. On the other hand, Jayaratha returns to this division among bubhukșus in his commentary on the 13th chapter, which is dedicated to the different degrees of śaktipäta, the descent of Śiva's divine power upon souls, which causes them to seek initiation. In this chapter, Abhinavagupta ranks the intensity of śaktipāta, relating each degreefrom highest, middle, and lowest, each further divided into three levels- to a certain kind of initiatory category. The principle is that the more intense the descent of power, the more immediate is the candidate's final liberation; and by this criteria he is to receive the appropriate form of initiation. ${ }^{32} \mathrm{On}$ this scale, the enjoyment-seeking bubhukșu is at the lower end, but Abhinavagupta himself does not make explicit how he correlates different degrees of śaktipāta to the śivadharmi and lokadharmī initiates. Rather, he restricts himself to the bubhukșu, assigning the middle (madhya-madhya śaktipāta) and lower levels (manda-madhya śaktipāta) of the middling kind of śaktipāta to two unspecified categories thereof. Of those, the middle level is for the bubhu$k s ̦ u$ who attains Śivahood after enjoying the siddhis of his respective tattva, ${ }^{33}$ and the lower level for the bubhukșu who enjoys siddhis in his subsequent

31 Tantrāloka 15.27-30: abhāvaṃ bhāvayet samyak karmaṇām prācyabhāvinām (< Svacchanda [Sv] 4.141ab: prākkarmabhāvikasyātha abhāvam bhāvayet tadā) | mumukṣor nirapekșasya prārabdhr ekạ̣ na śodhayet (< Sv 4.141cd: mumukșor nirapekșatvāt prārabdhr ekam na śodhayet) || sādhakasya tu bhūtyartham ittham eva viśodhayet (< Sv 4.142ab: sādhakasya tu bhütyartham prākkarmaikam tu śodhayet) | śivadharminy asau dīkṣā lokadharmāpahārin̄i (< Sv 4.143ab: śivadharminy asau dīkșā lokadharminyato 'nyathā) ||adharmarūpin̄ām eva na śubhānāṃ tu śodhanam (< Sv 4.143cd:prāktanāgamikasyāpiadharmakșayakārin̄ī)| lokadharminyy asau dīkșā mantrārādhanavarjitāa (<Sv 4.144ab: lokadharminy asau jñeyā mantrārādhanavarjitā) || prārabdhadehabhede tu bhuñkte 'sāv aṇimādikam (< Sv 4.144cd: prārabdhadehabhede tu bhunkte sa hy aṇimādikān) | bhuktvordhvam yāti yatraișa yukto 'tha sakale 'kale (< Sv 4.145ab: bhogān bhuktvā vrajed ürdhvam guruṇa yatra yojitah | sakale nișkale vāpi śișyācāryavaśād bhaved) ||, "He should destroy all the past and future karmas for the liberation-seeker who is indifferent. He should only purify the prārabdha karma. For the Sādhaka he should purify [the karmas] in the same manner for the purpose of powers (bhüti). This is the śivadharmiṇi dīkșā, which removes the worldly religion (lokadharmāpahārin̄ī). The purification of only the bad karma, and not the meritorious, is the lokadharmini dīkșa, which is without the worship of mantras. Upon the death of his current body he enjoys [the supernatural powers], starting with animā; and having enjoyed these he goes upwards to where he was joined [during the initiation ritual], at a sakala or nișkala level."

32 See Takashima 1992, 72-75, who explains the different levels of śaktipāta and the corresponding initiation categories. Tantrāloka 13.242. See also Takashima 1992, 72-73. 
rebirth and only attains union with Śiva after that. ${ }^{34}$ In his analysis of this chapter, Takashima $(1992,73)$ points out that the śivadharmini and the lokadharmini division would fit these two respective levels well, yet Jayaratha's commentary nonetheless interprets these differently. He instead equates the two levels of bubhukșu with two levels of the śivadharmī Sādhaka, a distinction encountered in the Mrgendra passage above, which spoke of an ordinary Sādhaka and one who retains his body until the time of cosmic dissolution. ${ }^{35}$ It is of course not clear whether Jayaratha had precisely this distinction in mind, but be that as it may, by assigning these two levels to the sivadharmini category, Jayaratha frees up the category of the lokadharmi Sādhaka to cover the three remaining, lowest levels of śaktipäta, which are concerned appropriately with practices focused on worldly enjoyments. ${ }^{36}$ In order to create three levels of lokadharmi, he uses the following distinctions, according to which the way to liberation is increasingly remote: the highest (tiv ra-manda śaktipāta) concerns the lokadharmī who automatically attains Śivahood after an interval of of some period, which he spends in a desired cosmic levela category of lokadharmi Jayaratha equates with the standard form we have so far encountered; ${ }^{37}$ the second highest (madhya-manda śaktipāta) concerns the lokadharmi who is initiated again in another world before reaching liberation; ${ }^{38}$ and the third (manda-manda śaktipāta) concerns the lokadharmi who first experiences enjoyments for a very long period, as well as different levels of proximity to the deity (sālokyasāmīpyasāyujyāsādanakrameña) ${ }^{39}$ of the cho-

34 Tantrāloka 13.243. See also Takashima 1992, 73.

35 See p. 255. Note that this passage caused some confusion of interpretation, even for Nārāyaṇakanțha.

36 Tantrāloka 13.245c-246b. See also Takashima 1992, 73 .

37 Jayaratha even quotes the Mrgendra (cf. note 25) passage at this point, ad Tanträloka 13.246: yaḥ kaś cit tī̄ramandaśaktipātavāṃl lokadharmī, sa dīkșābalāt dehānte kva cana yathābhimate bhuvanādau bhogān bhuktvā śivatāạn yāyāt | yad uktaṃ: lokadharmiṇam āropya mate bhuvanabhartari | taddharmāpādanam kuryāc chive vā muktikāṃkșinam I|, vakșyati ca: prārabdhadehabhede tu bhunkkte 'sāv animādikam | bhuktvordhvam yāti yatraișa yukto 'tha sakale 'kale ||. See also Takashima 1992, 73.

38 Jayaratha ad Tantrāloka 13.246: kaś cic ca madhyamandaśaktipātavān kva cana bhuvanādau kañ cit kālaṃ bhogān bhuktvā, tadīśvaradīkṣitah paryante śivatām gacchet.

39 On these different grades of "theistic liberation," see Watson et al. 2013, 249-25o, note 154; and Goodall 1998, xxxvii-xxxix, note 85. As Watson et al. (2013, 249-250 and note 167) discuss, an example of a "lower" level of liberation, associated with paurānic spiritual goals, is to become a ganapati, or chief attendant, of the lord, thus experiencing being in the same world (sālokya) as the Lord or in his vicinity (sämīpya) — spiritual goals, as the authors point out, which are also expressed in the lay literature of early medieval India, such as the old Skandapurāṇa and Śivadharmaśāstra. 
sen universe, and only then receives initiation again, through which he attains Sivahood ${ }^{40}$ In creating these different levels, Jayaratha might have had a system similar to the Mrgendra in mind, where we also found various levels of lokadharminī dīkșā, whose recipients range from those seeking final liberation to those who want to be united with and experience enjoyments related to a non-Śaiva deity. ${ }^{41}$ lokadharmiṇi dīkșā

Thus, to sum up, the following five features consistently appear in descriptions of the lokadharmi initiate:

1. His source of merit lies in lay religion, the lokadharma, namely what is taught in śruti and smrti.

2. During initiation all the bad karma connected with any level of reality is to be purified, leaving good karma intact to be enjoyed by the initiate.

3. He is not entitled to perform the propitiation of mantras (mantrāāa dhana).

4. He experiences supernatural powers after death.

5. He can choose whether he eventually attains ultimate liberation, or instead union with any deity of the cosmos he wishes; in the case of the Mrgendra these include even non-Śaiva, brahmanical deities.

For obvious reasons, this initiatory category is difficult to position within a Śaiva doctrinal framework, for it offers not only enhanced merit through destruction of all bad karma, but also attainment of any cosmic level, including liberation, without the commitment to perform Śaiva ritual with mantras. In this light, even the very label "Sādhaka" to such a candidate appears inappropriate, given the Sādhaka's paradigmatic association with seeking supernatural attainments through the power of mantras. Perhaps with this hesitation in mind,

40 Jayaratha ad Tantrāloka 13.246: mandamandaśaktipātavān punas tatraiva sālokyasāmīpyasāyujyāsādanakrameṇa cirataram kālam bhogān bhuktvā, tata eva dīkṣām āsādya śivatām iyat. See also Takashima (1992, 73), who has a slightly different interpretation of the sālokyasāmīpyasāyujyāsādhanakrameṇa, taking it to denote "various stages of enjoyment."

41 Cf. pp. 257-256. Note that in his conclusion, Takashima (1992, 74-75) proposes that Abhinavagupta intended the manda level of śaktipāta for those who only received samayadīkșā, contrary to Jayaratha's interpretation of different levels of lokadharmì initiates. 
Kșemarāja ad Svacchanda 4.85, offers a weak explanation for the lokadharmī being called a Sādhaka, leaning on the meaning of the underlying verbal root "sādh-," "to be successful, achieve;" he says that the lokadharmi is referred to as a Sādhaka "because he achieves (sādhanāt) the fruit by his pious acts alone."42 One could argue that a stronger reason to refer to the lokadharmī as a Sādhaka is that he will experience supernatural powers, like the Śaiva Sādhaka, except that he does so after death. Yet this addition to the professed outcome of the lokadharminī dīkșa seems almost to be a doctrinal elaboration added to warrant its place among Sādhaka initiations. Another sign that the lokadharmin̄i dīkșa held a doctrinally difficult position might be the meager commentary these passages receive. Bhațta Nārāyanakaṇtha, for instance, restricts himself to rather self-explanatory comments on the entire lokadharmini $\bar{\iota}$ passage in the Mrgendra.

Regardless of this awkward near-silence, at least for these scriptural sources and Kashmirian Śaiva authors, such an initiatory category appears to have been a social reality that needed to be accommodated and acknowledged. In addition to the sources discussed, the lokadharmini lsivadharminī distinction also features in a fourteenth century Kashmirian initiation manual, the Kalädīkșāpaddhati of Mānodatta, ${ }^{43}$ and Kșemarāja introduces these initiatory categories into his commentary on the Netratantra, even though the root text itself does not contain them. ${ }^{44}$ Additionally, we have seen how Jayaratha uses the category of the lokadharmī Sādhaka to speak of initiates who pursue mundane spiritual goals, giving the impression that there exists a wide range of lokadharmi initiates with different degrees of involvement in the Śaiva religion, similar to the model in the Mrgendra.

However, the question remains why such an initiatory category, which seems so counter-intuitive and difficult to justify doctrinally, came into existence in the first place. From a socio-historical perspective, the creation of a bubhukșuorientated exoteric form of Śaiva initiation appears to be connected to the position of tantric communities in an early phase, when the sphere of the

42 Kṣemarāja ad Svacchanda 4.85: śubhakarmaṇaiva tu phalasya sādhanāt sādhako 'yam.

43 I thank Professor Alexis Sanderson for sharing with me his handout, "Bhațta Rāmakaṇtha's commentary on the opening passage of the Matangapārameśvara," which quotes the Kalädīksāapaddhati on this point (pp. 36-37), and through which I found out about the usage of the śivadharmī/lokadharmì categories in this manual. For more information on Manodatta's work, see Sanderson 2004, 362, note 34.

44 See Kșemarāja ad Netratantra 4.1: bhuktidīkșā śivadharmalaukikadharmabhedena bhinnā sādhakasya, "The bhuktidīkșā for the Sādhaka is divided into the śivadharma and laukikadharma kind." 
power-seeking practitioner had a more prominent role. Brunner $(1975,439)$ long ago noted that the Svacchanda and the Mrgendra - both of which contain

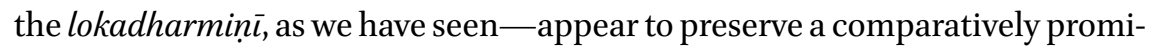
nent position for the power-seeking Sādhaka, which she suspects harkens back to an early phase of the tantric traditions, when the gulf between soteriological and power-orientated goals was not so vast. Her hypothesis finds confirmation in findings of the past decade, particularly those resulting from study of the Niśvāsatattvasaṃhitā (Goodall et al. 2015). As the earliest extant Śaiva tantra, the Niśvāsa affords important insights into the early stages of the "tantric age,"45 particularly in that — as Goodall points out - it envisages a time when tantric communities appear to have been restricted to limited esoteric circles ${ }^{46}$ with much focus on the propitiation of mantras for magical purposes, which were pursued prior to liberation. He further observes that the classical fourfold hierarchy of Samayin, Putraka, Ācārya and Sādhaka is entirely absent at this stage, with all practitioners simply referred to as Sādhakas - a category of initiates associated with the utilization of mantras for both supernatural powers and liberation. The community had not yet been divided into those who sought one to the exclusion of the other. ${ }^{47}$ That the pursuit of power and soteriological goals belonged to the same spiritual path is reflected in the Niśvāsa's initiation system, which teaches rites of two types, namely vidyā $\bar{i} k s \bar{a}^{4},{ }^{48}$ through which a candidate is admitted to the community and becomes a Sādhaka with authority to propitiate mantras, and the muktidīkșa, through which the confirmed Sādhaka attains liberation. ${ }^{49}$ Of neither initiation is there an exoteric form at this stage..$^{50}$

Theoretical repercussions caused by separating the liberation- and powerseekers' goals are visible, for instance, in the ambiguous treatment of karma's

45 The Niśvāsa is the earliest extant tantric scripture, preserving a stage of the development of tantric communities where non-tantric, Atimārgic roots are often visible, as Sanderson (2006) observed.

46 On the absence of the domain of social ritual in the Niśvāsa, see Goodall et al. 2015, 47.

47 See Goodall et al. 2015, 47-50. As for all initiates probably being referred to as sādhakas at this stage, see also Goodall et al. 2015, 281.

48 See Goodall et al. 2015, 5o. And, in fact, the dīkșa for the Sādhaka is sometimes referred to as vidyādīkșā, as in the Tantrasadbhāva. For more see Goodall's entry nirvānadīkșā in Tāntrikābhidhānakośa, vol. III.

49 See Goodall et al. 2015, 28o-282, 289. However, Goodall also notes that this interpretation that any initiate takes first the vidyādīkșa and then the muktidīkșa is a working hypothesis at the moment, not completely excluding the possibility that these may be two separate modes of initiation, which at the same time seems less likely.

See also Goodall et al. 2015, 51 . 
elimination during the initiation ritual for the Śaiva Sādhaka. ${ }^{51}$ Nevertheless, we find that the status and centrality of the "original" Sādhaka's position and practices are preserved in most early tantric scriptures, even after the community came to be divided into different initiatory ranks, and centered around the Ācārya and liberation-seekers. It is tempting to conclude that the creation of the lokadharmiñ dì kșā is directly connected to this early sphere of tantric religion, which put so much emphasis on the pursuit of magical powers and benefits. While in due course Śaiva literature grew to put more emphasis on the soteriological aspirations of the mumukșu-reflected in the fact that the soteriological-orientated nirbija di kșā has a more prominent role-the attraction of the powers and benefits gained through mantras must nonetheless have played an important role in the initial popularization of tantric groups. For the lokadharmiṇi dīkșa would hold obvious attractions for laypeople desiring to enhance the fruits of their current practice without committing to the disciplinary regimen of tantric Śaiva ritual. Another appealing aspect may have been that through this initiation, a lokadharmi became part of the initiatory community and perhaps privy to services accessible only to initiates, especially those offered by Śaiva Sādhakas. That broadening access to initiation may have played an important role in popularizing tantric Śaivism at an early stage is suggested by the fact that the Mrgendra extends the scope of the lokadharmini dīkșa to those who are not even Śiva-worshippers, people who may nonetheless have desired specific services distinctive to the Śaiva tantric domain. However, the doctrinally awkward position of the lokadharmī Sādhaka, combined with the increasing emphasis on purely soteriological goals, may have led to the gradual oblivion of this category, causing its reassignment in later sources, as will be seen below.

$5^{1}$ See ibid., pp. $254 \mathrm{ff}$. I am not aware of an established, coherent theory on what kind of karma needs to be left in place in order to pursue supernatural powers. But note that -in quite a different context - the idea that the success of a Sādhaka's practice is intertwined with his karmic position is also found in the Brahmayāmala. In his analysis of the chapters on the Sādhaka, Kiss shows how the Brahmayāmala teaches complex mechanics underlying a logic of karma, according to which the level of a Sādhaka's practice is dependent on actions in past births and on whether he had received initiation in a past life, as well as special rituals to remove karmic bonds that would block the success of the Sādhaka's practice (see Kiss $2015,35^{-55}$, in particular $5^{2-} 53$ concerning the rites to remove karmic bonds). 
The two other early Śaiva scriptures which make a distinction between śivadharmin̄ $\bar{\imath}$ and lokadharmini initiations are the Jayadrathayāmala ${ }^{52}$ and the rather later Brhatkālottara, both composed after the Svacchanda, and in the latter case certainly after the Mrgendra as well. However, in both of these works the association of these initiatory categories with the Sādhaka gets lost; they become reassigned to the context of nirvānadīkșa, the initiation for those seeking liberation rather than supernatural powers and enjoyments. However, unlike the Brhatkālottara, the Jayadrathayamala preserves in part the original logic of karma-elimination seen in the bubhukșu category of lokadharmin̄i dīkșā, despite this reassignment.

In the Jayadrathayāmala we find both of the initiatory categories in question-here referred to as śivadharmadīkșa and lokadharmadīkșā-in the description of initiation types ${ }^{53}$ outlined in the first șața. This is the portion of the text which Sanderson $\left(2007,235^{-236}\right)$ identifies as its oldest layer, deriving originally from a work called the Śraścheda. Unlike the Svacchanda and Mrgendra, the Jayadrathayāmala does not here employ the broad division between the mumukșu and bubhukșu in its exposition of initiatory categories, but rather makes a distinction between an initiation that bestows adhikāra, that is to say the authority to perform certain rituals, ${ }^{54}$ and those that bestow liberation $($ mokșad $\bar{a}) .{ }^{55}$ In presenting the latter, the nirvānadì $s s ̣ \bar{a}$, the

$5^{2}$ In search for references and access to this passage in the Jayadrathayamala I am grateful to several people: to Dominic Goodall, who first drew my attention to the fact that the lokadharmin̄ features in the Jayadrathayāmala; to Olga Serbaeva, for searching her etext and locating references for me, which showed that the thirteenth chapter is relevant; to Csaba Kiss, for sharing with me the paper manuscript of this chapter; and to Alexis Sanderson, for sharing his preliminary edition of the passage, which is quoted below in note 57 , and for reading and discussing the passage in question with me.

53 The immediate context here is Devi's question to Bhairava about the number of initiatory categories as well as the issue whether the initiatory procedure is the same for all four caste-classes.

54 The passage is problematic, and it is not specified what exactly is intended by the category of adhikāradā initiations. We may hypothesise that this refers to a kind of initiation that bestows to Śaiva office holders—i.e. the Ācārya and the Sādhaka—entitlement (adhikāra) to perform rituals for others. See Goodall's entry on niradhikāradīkșā in Tāntrikābhidhānakośa, vol. III. See also note 83 for an example of the pair adhikāradā and niradhikāradā dīkșā in a list of initiation types in the Somaśambhupaddhati.

55 The Jayadrathayamala (1.13.3) appears to want to impose this distinction already on the Samayadīkșā, which would be unusual, since the Samayadīkșā by itself typically cannot grant adhikāra. For the Sanskrit text and translation, see note $5^{6}$. 
Jayadrathayāmala teaches the following options: ${ }^{56}(1)$ the śivadharmadīkșā, (2) the lokadharmadīkșa, and (3) the kșipraghnī, which appears to be a synonym of the sadyonirvānaadīkșa (i.e. "the initiation that instantly grants liberation").

$5^{6} \quad$ As mentioned earlier (note $5^{2}$ ), a preliminary edition of this passage was kindly made available to me by Alexis Sanderson, who has also discussed the passage with me, helping to clarify points for the translation. I quote his text below, except that I mark his conjectures with "conj. S.," and degeminate doubled consonants after " $r$ " (any mistakes in the text and translation are, of course, my own). Jayadrathayāmala, Șațka 1, 13.3-18: sā *samay-

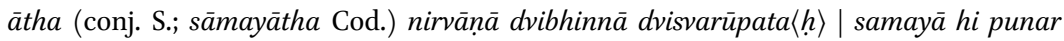
yāti dvibhāvam phalabhedatah $\|3\|$ jñ̄annayogapravrttisthā prāṇinām adhikāradā | tadvāsanavadhä *nityaryāpti (conj. S.; nityā vyāpti Cod.) pada pra dāyikā ||4\| * samayā (conj. S.; sāmayā Cod.) †yac ca† vijñeyā nirvānāāpi dvirūpin̄ī| "mokșādhikārabhedābhyām (conj. S.; mokșārthikārabhedābhyām Cod.) †sthānubhis tantravedibhiḥ $\dagger\|5\|$ bhūyo vimuktidā dīkṣā nirvāṇā bahubhedagā | śivadharmmā *lokadharmmā (conj. S.; lokadharmmī Cod.) kșipraghnī piṇdapātikā \|6\| *ekatamādhvacicchuddhyā (conj. S.; ekātamodhvacicchuddhyā Cod.) vyā vrtte bandhanatraye | śivāptidarśitāseseșa (conj. S.; śivāptidarśitāśeșa Cod.) samayācārapālanāt || 7|| mokșāvāptikarīyā tu lokācāraviparyayāt | śivadharmā smṛtā dīkșā dvisvarūpa ${ }^{*}$ "maheśvari (corr. S.; maheśvarī Cod.) ||8|| nirbïjākhyā * sabījā (conj. S.; savīryā Cod.) ca dīkșābhedah śivāgame | pākamūrkhasudīrnāñga- "edaka(conj.; eḍatva Cod.)kuniyoṣitām ||9|| *sarujātyantyabhaktānāṃ (conj. S.; saruḍātyantabhaktānāṃ Cod.) bhübhṛt-

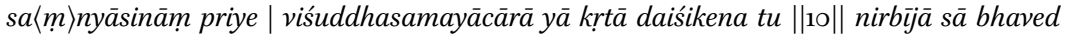
dīkșā sabïjā syād vilomatah | ${ }^{*}$ vidvad(em.; vidhi Cod.)dvandvasahānām tu sundari kriyate tadā ||11|| gurudevāgnikāryāṇiyaị kāryāṇi subhaktitạ̣| akurvatāṃ hi tat teșām vāãnchitam na bhavet phalam ||12|| lokadharmā tu yā dīkșā sā syāt sthitivilomagā | śivadharmakriyā sā tu kin tu laukikavrttigā ||13|| śodhayed atha vā sarvam dharmam ekam na śodhayet | laukikācāradharmasthạ̣ tad bhuktvā nirvrtịn vrajet ||14|| athāsitam viśodhyam tu karmaikam daiśikena tu | malino 'dhvāthavā devi *sodhyo bhogo (conj. S; śuddho bhogyo Cod.) na jāyate $\|15\|{ }^{*}$ na bhogyam tad dhi bhuktatvāt (conj. S.; tad bhogyam tadvibhuktatvā Cod.) prayāty àtmā param padam | smrteyam *lokadharmā (conj. S.; lokadharmī Cod.) tu dīkṣā *nirvānagāaminī (em. S.; nirvvāṇamāminī Cod.) ||16|| eșātīte niruddhe tu prārabdhe karmaṇi priye | kșinanabhogyavaśād yā tu sā dīkșā piṇ̣̂apātikā ||17|| kṣurikāstrogramantraiś ca *yogenādāya (conj. S.; yogenādhāya Cod,) prakșipet | parayogasamāyoge sadyonirvāṇadā hi sā $\|18\|$, "And that [initiation] is either a Samayadīkșā or Nirvāṇādīkșā, divided into two because it has two natures. Now the Samayadikșā is further twofold because of a difference in the result (phala). [The first] bestows adhikāra [and] follows the practices of jñana and yoga, [the second] destroys the latent impressions (vāsana) of that [soul?] and bestows a state of eternal pervasion [with the deity]. $\dagger$ [That is known] by the firm ones who know the tantras. $\dagger$ Besides (bhüyas) the nirvānadīkșā bestowing liberation is of many kinds: śivadharma[dīkșa $]$, lokadharma [dikkșā] and the initiation which kills quickly, causing the body to fall. [The initiation] which reveals everything through the attainment of Śiva (śivāptidarśitāseșā) through the performance of post-initiatory rites (samayācārapālanāt) once the three bonds (i.e. the three impurities (mala)) have ceased due to the purification of the consciousness on one [of the six] paths, [that] initiation is known to be the śivadharmadīkșā, which bestows the attainment of liberation (mokșāvāptikarī) because it is contrary to the mundane practice. [And], O Goddess, [the Śivadharmadīkșā] has two forms: in Śaiva scriptures the division of initiation 
Of those, the śivadharmadīkșa is defined as twofold, namely sabija (i.e. with the seed of post-initatory practice) and nirbijja (i.e. without the seed of postinitatory practice), which amounts to the bifurcation we typically expect of nirvānadīkșā. The śivadharmadīkșā initiate therefore attains liberation at death, either with the stipulation to perform post-initiatory rites (sabijā) or without this stipulation (nirbijjā). The lokadharmadīkșā variations, on the other hand, lead to liberation only after the initiate has enjoyed the merit earned through his mundane ritual practice. In this category, two versions are taught: first is the lokadharmini $\bar{\imath}$ kind, which we have already encountered in the Svaccha$n d a$, Mrgendra and Tantrāloka, namely an initiation involving the elimination of all bad karma, leaving meritorious karma in place to be enjoyed before the eventual attainment of liberation. The second appears to be a version of the lokadharmadīkșā in which only the impure universe is purified, the idea being that the initiate will go to some segment of the pure universe after death. ${ }^{57}$

is called that without the seed (nirbīja $k h y \bar{a})$ and that with the seed (sabīja $)$. The Ācārya performs the [initiation] which contains the duty to perform post-initiatory rites purified (viśuddhasamayācārā) for children, imbeciles, those whose limbs suffered trauma, deaf people, women, people who are suffering from chronic illness and kings and renouncers (samnnyāsin) who are extremely devoted [to Śiva]; this [initiation] is the nirbüjā. The sabïjā is the opposite to this and is performed, $\mathrm{O}$ beautiful one, for those who are learned, endure extremes and are able bodied. By those the rituals towards the Guru, the God and the fire have to be performed with extreme devotion, since the desired fruit will not come about for them who don't do [these rites]. The lokadharmadīkșā is a Śaiva ritual [and therefore] proceeds contrary to established [practice] (i.e. the brahmanical order), but also conforms to worldly religion. Either [the Ācārya] should purify all [karma] or only not purify the dharma (i.e. the auspicious karma); [then the initiate] is dedicated to [the accumulation of] dharma through mundane observances (laukikācāradharmasthah), and having enjoyed this [dharma] he proceeds to liberation. Thus, the Ācārya should only purify the bad [karma]. Alternatively, (athavā) [only] the impure path is purified, [so that] no experience (bhogah) comes about [in the impure universe]. [In other words] that [experience] does not have to be experienced [anymore in the impure universe] because it has already been experienced [through the process of initiation]. The soul [of the initiate] (âtma $)$ goes straight to the higher level (i.e. the pure universe). That is known to be the initiation called lokadharma, which leads to liberation. Such [an initiation] (i.e. the śivadharmaor lokadharmadīkșā?) [is performed] when the past action has been destroyed, but the prārabdhakarma [is present], $\mathrm{O}$ loved one. But that initiation which [is performed] after [all experiences that] need to be experienced have waned, that is the pindapātika (i.e. which causes the dropping of the body). [The Ācārya] should take hold [of the soul] through yoga and expel it with the razor and other fierce mantras in order to bring its union [with the deity] through the highest fusion (parayogasamāyoge). For this is the [initiation which] bestows liberation immediately (sadyonirvānadā)."

For the interpretation of the second kind of lokadharmadikșā I am indebted to Alexis Sanderson. 
While our sources discussed so far did not teach such a variation of the loka-

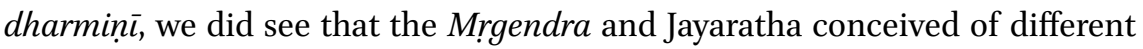
levels of lokadharmi practice, the latter even adding a level in which the lokadharmi is reborn and then initiated again on another cosmic level. ${ }^{58}$ The śivadharmadīkșā and the lokadharmadīkșa thus differ broadly from each other in that the former bestows spiritual liberation through the power of Śaiva ritual alone, being opposed to the worldly practice (i.e. mokșvāptikarìya tu lokācāraviparyayāt $\mid$ śivadharmā smrtā dīkșā), while in the latter brahmanical ritual acts as the source of the immediate spiritual benefit, even though - as in the earlier cases - the power of initiation eventually brings about union with a deity on some or another cosmic level. That in the Jayadrathayamala too this category holds a doctrinally awkward position can perhaps be inferred by the need the redactors felt to stress that the lokadharmadīkșa $\bar{a}$ is indeed a Śaiva ritual (Jayadrathayāmala, Șațka 1, 13.12). ${ }^{59}$

In the case of the Brhatkālottara, the śivadharminīllokadharminī terminology makes only a brief appearance. So far I have only been able to locate a single passage featuring this distinction, at the end of the chapter on initiation. ${ }^{60}$ Here too these categories are not used in the context of the Sādhaka or bubhukșu, but feature rather as variations of the nirvānadīkșa. In contrast to the Jayadrathayāmala, the pair is used to describe the nirbijā dīkșa and sabìjā dīkșā, respectively, and in the case of the lokadharminī, there is no reference to the elimination of bad karma alone. What is curious is that the text, as preserved in the manuscript available to me, equates nirbijjā dīkșa with the śivadharmin̄i and sabija with the lokadharmini. ${ }^{61}$ This seems counterintuitive, since in all the classifications we have seen the sabija is the initiation after which a candidate is obliged to observe Śaiva post-initiatory rites (samayas) until death, whereas in the nirbij $\bar{a}$ case, the initiate is free of this obligation and maintains his ritual obligations in accordance with his position in society. It is tempting to conjecture that the transmission of the text is simply wrong at this point - that we should emend the order so that the nirbija is equated with lokadharmini $\bar{\imath}$ and the sabija $\bar{a}$ with śivadharminī. However, this remains conjectural, and a more thorough study of the initiatory categories will require critically editing at least

\footnotetext{
$5^{8}$ See here, pp. $255 \mathrm{ff}$. and pp. $261 \mathrm{ff}$.

59 For the Sanskrit text and translation, see above, note 56.

6o The text has not been critically edited yet and to my knowledge only some parts of it have been transcribed electronically, kindly shared with me by Nirajan Kafle; the passage in question appears at the end of what is termed "dìkșāpatala" in the palm-leaf manuscript, also kindly provided to me by Nirajan Kafle.

61 Bṛatkālottara 43r, line 2-3: nirbījā śivadharmakhyā sabüjā lokadharmin̄i, "The nirbïjā is called the śivadharma[dīkșā], the sabijā is the lokadharminī."
} 
this portion of the text. Nevertheless, what we can extract for our discussion is that here the classification is associated neither with the Sādhaka, nor with the "karma logic" of the lokadharminī dīkșā found in the Jayadrathayāmala.

\section{5}

\section{Pre-13th Century Saiddhāntika Manuals: Householders versus Ascetics}

Labels for the initiation categories śivadharmiṇi and lokadharmiṇi are carried over into the Saiddhāntika manuals, though differently and inconsistently reassigned by various sources, and with weak links to the original Sādhaka context. The following surveys early Saiddhāntika manuals, with particular focus on the earlier sources, but is not exhaustive. Noticeably, the influential Somaśambhupaddhati, also called the Kriyākāṇ dakramāvalī, of Somaśambhu does not teach a mundane form of the sādhakadīkșa, nor does it include lokadharmini among the mumukșu options; rather, the text speaks of the Śaiva Sādhaka receiving, as in the sources discussed earlier, a modified form of the nirvannadīkșā right before his consecration to office. ${ }^{62}$ However, in the description of the sabijja nirvānadīkṣa, at the point when karmas are emplaced upon the pāśasūtrarepresenting all reality levels of the cosmos, which will be burnt and destroyed in the consecrated fire-the Somaśambhupaddhati presents various options for the karma that can be exempted from purification, namely the prärabdhakarma, the karma for mantrasiddhi, and the karma that results from meritorious acts, comparable to those of the lay devotee. While Somaśambhu himself does not explicitly correlate these options to specific initiation types, we may note that the latter two categories of karma, to be exempted for purification in certain circumstances, correspond to the procedures we have seen envisaged for the śivadharminī initiation for the Śaiva Sādhaka, and the lokadharmiṇı initiation, respectively. In fact, in his commentary on this passage, Trilocana explicitely assigns these categories accordingly. ${ }^{63}$

62 See, Somaśambhupaddhati Sādhakābhișeka 1-2: sādhaskyābhișeke tu nivrtyādikalātrayam | mumukșor iva saṃśodhya śāntyatītām viśodhayet || tatah sadāśivam dhyātvā mülamantreṇa pūrnayā | śāntau samyyojya kurvīta guṇāpādanam așțadhā. For a tanslation and notes, see Brunner 1977, 500-506.

63 Somaśambhupaddhati, Nirvānadīikṣāvidhi 31-32: sabījāyāṃ tu dīkșāyāṃ samayācārapāśatah | dehārambhakadharmāc ca mantrasiddhiphalād api || ișțāpūrtādidharmāc ca vyatiriktạ̣ prabandhakam | caitanyarodhakam sūkșmaṃ kalānām antare smaret ||. For a translation and annotation, see Brunner 1977, 190-196. For Trilocana's commentary on this passage, see Brunner 1977, 191, [32a] and notes thereon. 
Another manual from this period is the Vimalāvatī of Vimalaśiva, who composed his work in 1101/2 and lived in Vārānasīi (Sanderson 2014, 22). Vimalaśiva explicitly uses the categories of śivadharminì and lokadharminī; and though he partly draws on the passage from the Mrgendra examined earlier, he does not assign these to different kinds of Sādhaka, but rather assigns the śivadharmin̄ initiation to the Putraka and Ācārya-a feature we also see in the Ajitāgama ${ }^{64}$ - and the lokadharmiṇi simply to the Sādhaka devoted to meritorious action. ${ }^{65}$ However, it appears that in this passage the allocation of initiation categories has gone awry, such that the Śaiva Sādhaka is missing, unless the reason for this omission is the actual disappearance of the Sādhaka from medieval South-India.

Jñānaśiva wrote his Jñānaratnāvalī also while residing in Vārāṇasī, probably some decades later. ${ }^{66}$ In his application of the śivadharmin̄i/lokadharmini terminology he seems to be the most innovative of Saiddhāntika authors in this period. He also quotes sources for this classification that have yet to be identified. Jñānaśiva uses this terminology to denote divisions of the nirvāna adīkṣāthat is to say, the full regular Śaiva initiation-in essence in order to distinguish, broadly, between initiations performed for the ascetic practitioner, here the śivadharmī, and those for the householder practitioner, here the lokadharmī. ${ }^{67}$

64 Ajitāgama 77.14: sabüjā ca dvidhā bhinnā prathamā śivadharmin̄i || sādhakācāryayoh proktā deśakālādibhedanạ̣ | dharmādharmātmakaṃ karma prāgāgāmi vicitrakam || sañcintya śodhyate yatra saivoktā śivadharmin̄i | adharmamātrasaṃśuddhau dvitīyā lokadharmin̄il|.

65 Vimalāvatī f. 67r: dvividhā syāt sabījāpi tatrādyā śivadharmin̄ī| "*putrakācāryayor (conj.; putrakācāryayo Ed.) mukhyā dharmādharmakșayakarī || ișțāpūrtādinirate sādhake lokadharmin̄i || śivadharminy *anor (conj.; aṇau Ed.) mūlaṃ śivadharma*phalaśriyah (conj.; "phalam śriyah Ed.) | "hitetarā (conj.; hitatarā Ed.) vinä bhamgam *tanor (conj.; tannaur Ed.) à vilayād *bhuvām (conj.; bhavāṃ Ed.)|| bhogabhūmișu sarvāsu *dușkrtāmśe (conj.;

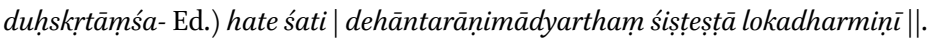

66 See Goodall 20oo, 209 for the date of Jñānaśiva. I am extremely grateful to Dominic Goodall for sharing with me his etext of the Jñannaratnāvalī as well as his photographs of the transcript $\left(\operatorname{Re} 1025 / 5^{2}\right)$ cited in this article.

67 Jñānaratnāvalī, p. 266: tatra tāvat * sāpekșānapekșā (conj.; sāpekșāpekșā Cod.) dvividhā śivadharmin̄i lokadharmin̄ī ceti. tatra tāvac chivadharmin̄i linginām śikhācchedasamāyuktā anyā gṛhināạn tadvirahitā. uktam ca: dvedhā nirvānadīkșā laukikís śvadharmiṇī| gṛhiṇām laukikì jñeyā lingināṃ śivadharmiṇī || śikhācchedo na yatrāsti dīkșā sā lokadharmiṇ̄ | śikhākhaṇdena saṃyuktā dīkșā sā śivadharmiṇi ||, "Therein, now, [the initiation types] are twofold, [namely] dependent on [whether] there is a requirement to perfrom postinitiatory practice or not; and [they are also twofold insofar as being] śivadharminī or lokadharmin̄i. Here [in the category of the sāpekșā nirvānadīkșā kind], the śivadharmin̄i is for ascetics and contains the cutting off of the topknot, while the other [initiation] is for householders and is without [cutting off the topknot]. And it is said: The nirvānadīkșa is twofold, [divided into] the mundane (laukikī) [kind] and the śivadharmin̄i. The mun- 
The actual procedures for the sivadharminī and lokadharmin̄i initiations are the same, being those for the nirvānadīkșa, with only one difference: for the śivadharmī, the topknot is cut off during the initiation, while for the lokadharmi it is not. ${ }^{68}$ The topknot is believed to contain the rodhaśakti, ${ }^{69}$ that is to say the power to delude the soul, ${ }^{70}$ which is apparently eliminated by cutting the topknot off in the case of the ascetic. This is not done for the lokadharmi, who, after all, is by definition still engaged in worldly activity. In terms of post-initiatory practice prescribed for the lokadharmī initiate, the Jñannaratnāvalī differs from the earlier scriptural sources discussed in the first part of the paper, in which an initiate who received a lokadharmin̄i or lokadharmadīkșā was only required to continue his ritual obligations of the brahmanical ritual sphere (the lokadharma), without Śaiva-specific additions. In the Jñānaratnāvalī, however, we have seen that the lokadharmin̄i is clearly defined as a form of nirvānadīkșā, which — unless otherwise specified—is of the sabija kind. Thus, the significance here is that the initiate retains his socio-religious status in mundane society (lokadharma) as a householder and keeps up these practices in addition to his Śaiva post-initiatory ritual obligations, a principle that is already expressed in early Śaiva sources. ${ }^{71}$ There is no mention of the procedure to

dane is known to be for householders, the śivadharmin̄i for ascetics. In the lokadharmin̄i initiation there is no cutting of the topknot. The initiation in which the topknot is cut off is the śivadharminī." At the end of this section, all the sāpekșā types are contrasted with the nirapekșā; see Jñānaratnāvalī, p. 269: evam sāpekșā bahudhā jñeyā nirapekșā ca parāparatvena dvividhā sadyosadyonirvāṇa ceti, "In this manner the sapekșā type is known to be manifold, and the nirapekșa type is twofold on account of its higher and a lower forms, [namely] the immediate and the not-immediate types of nirvānadīkșa."

68 For the Sanskrit text and translation, see note 67 . Note that this is not the case in all manuals; for instance, the Somaśambhupaddhati does not maintain this distinction. See Brunner 1977, 338, note 395 .

69 Also referred to as tirodhānaśakti.

$70 \quad$ See, e.g., Somaśambhupaddhati, Nirvāṇadīkṣāvidhi, verse 219 (Brunner 1977, 338-339): śikhāmantritakartaryā rodhaśaktisvarūpiṇīm | śikhām chindyāt śivāstreṇa śisyasya caturañgulām \|, and also Jñānaratnāvalī, p. 344: śikhāãn chidyāt tayā śaktyā rodhaśakti-

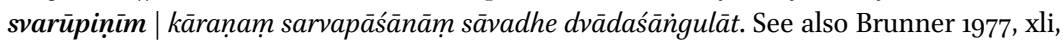
and for a discussion of the cutting of the topknot at other moments during initiation in some sources, see Goodall et al. 2015, 282-283.

71 Sanderson $(2009,302)$ has demonstrated how Śaiva scriptures and commentaries early on developed clear positions regarding the importance for Śaiva householder initiates of maintaining their brahmanical householder duties, i.e. the lokadharma. This helped ensure that Śaiva initiation remained attractive to the householder mainstream, who, in this way, were not required to completely transform their public lives. However, it is emphasised in these sources that such full Śaiva initiates were asked to maintain brahmanical practice merely for the sake of conformity, or in order to avoid transgression, not as a source of spiritual merit. 
eliminate only the bad karma linked to all reality levels, which we have seen associated with the lokadharminī dīkșā.

However, while this seems to be the underlying basic division of the nirvānadīkșa $\bar{a}$ in the Jñannaratnāvalī, these distinctions subsequently become entangled with aspects of the śivadharmin̄i and lokadharminī initiations stemming from their original Sādhaka context. This happens in the context of creating sub-categories for both the śivadharmin̄i and lokadharmin̄i categories, based on a division between those who desire something (sakäma), i.e. what would otherwise be called the bubhukșu, and those who do not desire anything except liberation (akāma, nișkāma), i.e. the mumukșu. For ascetic practitioners, the śivadharminī is divided into kinds for temporary ascetics (bhautika) and permanent ascetics (naișthika), ${ }^{72}$ and each of these is further divided into the sakāma and nișkāma type. ${ }^{73}$ In the case of the naișthiki sakāmā initiation, the initiate is promised enjoyments of the pure universe, after which he is to attain liberation. ${ }^{74}$ The naișthiki nișkāmā initiation, on the other hand, bestows liberation immediately. On the division of the bhautiki into sakāma and nișkāmā types, Jñānaśiva quotes the first two verses of a passage from the Mrgendra, which mentions that there are two types of bhautiki dīkșā, the superior and the inferior, the first being śivadharmin̄i and the second being the lokadharmin̄i type. ${ }^{75}$ However, since Jñānaśiva uses these as sub-categories

72 Jñannaratnāvalī, p. 266 (with a conjecture by Goodall recorded from the etext): tatra śivadharmiṇī dvidhā naișțhikī bhautikì ceti tatra niravadhitapasvino naișțhikāḥ. teșām yā sā naișthikī niravadhīty api kathyate dvitīy $\bar{a}$ *katipayadina(conj. Goodall, gādipayadina ms.) vratapālanād anantaram grhapadadāȳ |, "Here the śivadharmin̄i kind is twofold, [namely] naisțhiki and bhautiki. Of these (tatra) the naișthikas are permanent ascetics. The [initiation] that is [performed] for them is the naisthiki, that is to say the one called the permanent. The second [kind of initiation] (i.e. the bhautiki $)$ restores the state of being a householder immediately after the performance of an observance for a certain number of days."

73 Jñānaratnāvalī, p. 266: tatra naișthikì sakāmākāmabhedena dvidhāa, "In that case, the naișthiki initiation is divided into one for those who desire [enjoyments and supernatural powers] and one for those who don't."

74 Jñānaratnāvalī, pp. 266-267: tatra sakāmasya śuddhädhvabhogan datvā tadanantaram śivapadapradā sakāmā, "In that case, for the one who desires [enjoyments and supernatural powers] the sakāma $\bar{a}$ [initiation] [first] bestows the pleasures of the pure universe and immediately after that the level of the [highest] Siva."

75 For the Mrgendra passage, see pp. $256 \mathrm{ff}$. Jñānaratnāvalī, p. 267: *atha (em.; athā Cod.) bhautikī ca tathā dvividhā | uktạ̣ ca: evam eva krìyāyogād *bhautiky (conj.; bhaumity Cod.) api parāaparā | kin tu dehāviyogārtham prārabdhạ̣ karma mohinām || śaivasāadhanasādhyena sandhāya paripālayet | sānubandhạ̣ dahed anyad dīpte dīkșāhutāśane || asyāpy ayam arthah: evam eveti naișthika* sakāmākāmavad (conj.; -sakāmakāmavadCod.) bhautikasakāmākāmayor api kriyāyogāt kriyā ca yogaś ceti kriyāyogam | tat kriyā 
of the sivadharminit, this is not the way in which he wants the Mrgendra to be understood; rather, the prose after the quotation explains that the difference lies in the sakāma entailing purification of the impure universe only up to $m \bar{a} y \bar{a}$, thus providing enjoyments within the sphere of the pure universe; the niṣkamma type, however, entails purification of all levels of the universe, and the initiate thus attains liberation at death. ${ }^{76}$ If we are to understand these as two sub-categories of the temporary ascetic, the second type makes little sense, a confusion that is probably caused by the terminology bhautiki and naișthiki dīkșā in the Mrgendra, where the terms are not, in turn, synonyms of the bhautikavrata and naișthikavrata, ${ }^{77}$ as they are understood in the Jñanaratnāvalī. ${ }^{78}$

The lokadharmin̄i dīkșā, in turn, is divided into superior (para) and inferior (apara) forms. Of those, the superior version is what we expect of the nirvānadīkșā, with all karma but the prārabdha destroyed, the candidate thus being united with Siva at the end of the initiation ritual in anticipation of his ultimate liberation at the time of death. ${ }^{79}$ The inferior form is assigned to an initiation in which only bad karma is destroyed, thus the version of the lokadharmiṇi dīkșā seen in the Svacchanda and the Mrgendra. ${ }^{80}$ Jñānaśiva even

sakāmasya māyāntādhvaviśodhanam | niṣkāmasya samastādhvaviśodhanañ ca yogah | punaśśuddhādhvanibhogayogas sakāmasya niṣkāmasya śivayogaś ca [...], "Next, the bhau-

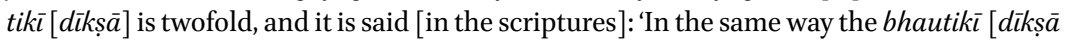
is achieved] through ritual and union [and] is also of a superior and inferior kind. Rather, for the [still] deluded [souls] he should preserve the prärabdha karma, which has the purpose of keeping [the initiate] with his [current] body, after joining it with [the karma] to be cultivated for the practice of propitiating Śaiva mantras for supernatural powers (i.e. śaivasādhana). The other [karmas] together with their consequences he should burn in the blazing initiation fire.' This is the meaning: 'in the same way' means through kriyayoga, that it to say the rituals and union [with the respective deity] for the sakāma and akäma bhautikī are just like those for the sakāma and akāma naișthikī. Therefore the ritual for the sakāma kind is the purification of the universe up to māyā. For the nișkāma it is the purification of the entire cosmic path and then union. Or rather, for the sakāma there is union with enjoyments in the pure universe, and for the nișkāma there is union with Śiva. $[\ldots] "$

76 Ibid.

77 See p. 254, note 19 .

78 See note 72 .

79 Jñānaratnāvalī, p. 268: atha lokadharmin̄i ca parāparatvena dvividhā. tatra parā śivatvadā. uktam ca: śivāśivātmakam karma śodhayitvādhvamadhyagam | yā yā nirvāṇam āpnoti sā parā lokadharmin̄i. iti, "Now the lokadharmin̄i is divided into the superior and the inferior. Of these the superior bestows Śivahood. And it is said: 'Having purified the pure and impure karma situated on the cosmic path (adhvamadhyagam), whichever [initiation] brings about liberation is the supreme lokadharmini [initiation]."

80 Jñānaratnāvalī, p. 268: *śarīrapātottaram (em.; śarīrapādotaram Cod.) abhilakșitabhuvane śiștāparālokadharmin̄i aparā punar abhilașitabhuvanaṃ yāvad adhvaśuddhau sa- 
quotes a verse which is shared with or probably original to the Mrgendra, though embedded in a quotation from a different, unidentified text, which reiterates that the initiate can be united with the deity of his choice at the end of the initiation ritual. ${ }^{81}$ However, what is not made explicit in any of these passages is what the practice after initiation consists of; since both of them are sabijadīkșās, we expect some form of post-initiatory practice to be applicable, which is fitting for the superior kind, but not for the inferior kind, as we have seen it so far. But given the context, we can probably assume that the intention is the same as it was in the original context, namely that the initiate of the lower (apara) form simply follows his lokadharma after initiation. However, it is difficult to know whether this reflects actual practice-that is, whether this categorization intimates the convention of giving initiation even to lay worshippers of non-Śaiva deities-or whether this is an artificial distinction created in the process of accounting for the Mrgendra's shared terminology. Another place where Jñānaśiva invokes the śivadharmiṇi /lokadharmiṇi distinction is regarding the post-funerary śräddha rituals, which vary according to initiatory types. Here, the mode of śrāddha for the śivadharmī appears to

tyām abhīstabhuvane 'py *aśubhāṃśakarmaniv̛rttau (conj.; aśubhām karmanivrtttau Cod.) tadbhuvaneśvara " gunān̄imādisiddhipradā (conj.; " gaṇānimādisiddhipradā Cod.). uktañ ca: bhogabhūmișu sarvāsu duṣkrtāṃśe hate sati | dehottarāṇimādyartham * *sișteșțā (conj.; śiștoșta- Cod.) lokadharmiṇi || iti, "The remaining one is the inferior lokadharmin̄i [initiation], [which] after death (śarìrapätottaram) [leads the candidate to] the universe he desired. But the inferior [lokadharminī initiation] bestows supernatural powers, starting with the power to become as small as one wishes, and the qualities of the deity presiding over the [respective cosmic level], after the purification of the cosmic path up to the level of the universe [the candidate] desires. And even on this desired cosmic level, the cessation of karma is [only] of the unmeritorious part. And it is said: 'The remaining [initiation], known as the lokadharmini, [is performed] for the purpose of [obtaining supernatural powers], such as the power to become as small as one wishes, in a subsequent body, after the bad portion of [karma] is destroyed on all reality levels [through initiation]." Note that the appropriation of the Mrgendra verse here to denote the inferior level of the lokadharminī dīkșā is not the original intention. Rather, the phrase śișteșțā lokadharminī denotes the second kind of bhautikì dīkșā, namely the lokadharminī itself, in contrast to the śivadharminī.

81 Jñānaratnāvalī, p. 268: *śivadharminam (conj.; śivadharminīm Cod.) äśodhya *yojayet (conj.; yo japet Cod.) parame pade | dehapāte ca *mokșas (conj.; mokșa Cod.) syāt samayācārapālanāt || *lokadharminam (conj.; lokadharmin̄im Cod.) āropya mate (conj.; made Cod.) bhuvanakartari | ${ }^{*}$ taddharmāpādanam (conj.; taddharmapālanam Cod.) kuryāc chive vā muktikāṃkșinām ||, "Having purified the śivadharmī, he should join him with the highest cosmic level, and after having performed his post-initiatory obligations liberation will come about at death. Having lifted up the lokadharmi to the desired [level] of the presiding deity, he should bring about the qualities of this [deity in the candidate] or [unite him] in Siva, for those who desire liberation." 
be that which is intended for ascetic initiates, while that for the lokadharmi is for householder initiates, thus being consistent with the basic distinction Jñānaśiva sets up in the beginning of the initiation section (Mirnig 2013, 292295).

The Jñannaratnāvalì's innovative application of the śivadharmin̄illokadharmini $\bar{\imath}$ terminology led to some interpretative confusion and inconsistencies in subsequent classifications, ${ }^{82}$ perhaps especially since the influential Somaśambhupaddhati does not mention this division of initiatory categories. ${ }^{83}$ Thus Trilocana, for instance, who is a student of Jñānaśiva and wrote a commentary on the Kriyākāndakramā $v a l \bar{\imath}$, when commenting on the initiation categories taught there, fits the śivadharminī and lokadharmin̄i initiations into Somaśambhu's system under the category of sāpekșā initiation, even incorporating such details as the difference in cutting or not cutting off the topknot. ${ }^{84}$ However, he runs into difficulties when mapping the initiatory categories onto the various forms of śräddha, which differ according to the initiate's spiritual status during his lifetime (Mirnig 2013, 296).

This distinctive idea that the topknot is be to cut off in the case of the śivadharmini initiation, but not in the lokadharmin̄i, is carried over into subsequent sources that include these categories in their initiatory classifications.

82 See, for instance, Brunner 1977, 194, note 71.

83 Somaśambhupaddhati, Samayadīkșāvidhi 5-13: nirādhārā ca sādhārā dīkșā tu dvividhā matā | nirādhārā dvayos teșām sādhārā sakalasya tu || ācāryanirapekṣeṇa kriyate śambhunaiva yā | tīvraśaktinipātena nirādhāreti sā smṛtā || ācāryamūrtim āsthāya mandatōvrādibhedayā | śaktyā yām kurute śambhuh sā sādhikaraṇocyate \|| iyam caturvidhā proktāa sabïjā bïjavarjitā | sādhikārā niradhikārā yathāvad abhidhīyate || samayācārasamyuktāa sabījā jāyate nrṇām | nirbījā tv asamarthānām samayācāravarjitā || nitye naimittike kāmye yasya syād adhikāritā | sādhikārā bhaved dīkșā sādhakācāryayor atạ̣ || nirbüjāàikșitānā̄m tu tathā samayiputrayoḥ| nityamātrādhikāritvād dīkșā niradhikārikā || dvividheyam dvirūpāpi pratyekam upajāyate | ekā kriyāvatī tatra kuṇamaṇdalapūrvikā || manovyāpāramātreṇa yā sā jñānavatī matā | itthạ̣ labdhādhikāreṇa dīkṣācāryeṇa sādhyate ||. For a translation and notes, see Brunner 1977, 4-13.

84 Thus, Trilocana's Somaśambhupaddhativyākhyā, p. 184, is somewhat similar to Jñānaśiva's text (see note 67): ... yā dīkșaiva sabījā, nirbījā, sādhikārā, niradhikāra ceti caturvidhā proktā. tatra tāvat samayācārasamyuktā yā sā sabījā. sā ca dvividhā śivadharmin̄ī lokadharmin̄i ca. tatra tāvac chivadharmin̄īsikhāyāśs chedasahitā. sā ca dvividhā naișthikībhautikī ceti. tāvan naișthikì niravadhiḥ. dvitī̄a à katipayadinavrataparipālanānantaram gṛapadadāyinī. And Trilocanaśiva ad Somaśambhupaddhati, Nirvānadīkșāvidhi 31, as quoted by Brunner 1977, 191, [32a]: atraivāvasare tāvan nirbüjinām dehārambhakarmaṇaḥ | sabijāyāṃ tu dīkāyām śivadharminyām samayācāradehārambhakakarmadvayāt | atha sādhakadīkșāyām mantrasiddhiphalād api | lokadharminyām iștāaūrtādidharmāc ca vyatiriktam prabandhakam kalānām antare smaret. For notes and a translation, see Brunner 1977, 190 , note 66 . 
Thus, the Siddhāntaśekhara (18-22b) ${ }^{85}$ of Viśvanātha, who wrote in Vārāṇasī in the first half of the thirteenth century (Sanderson 2014, 23), in essence teaches a structure similar to the Jñannaratnāvalī, with the sivadharmiṇi and lokadharmini $\bar{\imath}$ being the broad divisions of sabija initiation, except that the lokadharmin̄i is not further divided; the śivadharminī, in contrast, is divided into naișthiki and bhautiki varieties, but there is no further division into sakāma and nișkāma kinds. ${ }^{86}$

Even this brief survey of some early-medieval South-Indian sources, written some centuries after the sriptural material discussed in the first part of the paper, shows that there was no fixed consensus on what the different initiatory categories covered exactly; the same elements appear in various places, assembled together differently. ${ }^{87}$ What the sources share, however, is that these categories are no longer in any case associated with the bubhukșu category.

The material reviewed above allows us to trace how the emergence and development of the lokadharmini initiation are linked to larger developments in tantric Śaiva history. To sum up: the initial stage appears to reflect an early phase of tantric Śaivism, when the power- and enjoyment-seeking aspects of

85 Siddhāntaśekhara p. 145, Naimittikakānda, chapter 2.18-22b: sabījā dvividhā proktā prathamā śivadharmin̄i | dharmādharmātmakạ̣ karma sañcitāgāmicitrakam ||18|| saṃmrrdya sādhyate yasmāt sā dīkṣā śivadharmiṇ̄ | adharmasañcitam sarvaṃ karmāngam iva śodhyate ||19|| dharmāvaśeșito yatra sā dīkșā lokadharmiṇī| tatrādyā saśikhācchedā na śikhācchedanādarā ||2o|| bhautikī naișțikī ceti dvidhā sā śivadharminī | vratamokșasamāyuktā bhautikîti nigadyate ||21|| śarīrapātaparyantā yathā sā naișthikī matā |.

86 See, for instance, Nigamajñāna II's Dīkșādarśa, for which see Ganesh 2009, 196; see also further mention of these categories on pp. 137, 164-165, 196, and 240.

87 For instance, in the 16th century Śaivaparibhāṣā (for the date of which see Sanderson 2014, 86) of Śivāgrayogin, the śivadharmiṇi and lokadharmin̄i are differentiated according to an original feature: that for the former all karmas are destroyed, and for the latter only the bad ones. The feature of cutting off the topknot, on the other hand, is connected with the nirvānadīkșā as opposed to the samayadīkșā and viśeșadīkșā; however, the text does link the cutting of the top-knot to the ascetic, saying that it should take place after his nirvāna àikșā; see Śaivaparibhāṣā, chapter 5, p. 5: iyam api śivadharmin̄i lokadharmin̄i ceti dvividhā. dharmādharmayor ubhayor api yatra samśsodhanam sā śivadharmin̄i. adharmamātrasya yatra saṃśodhanam sā lokadharminīi. kriyāvatī prakārāntareṇa trividhā. samayadīkșā viśeșadīkșā nirvāṇadīkṣā ceti. yatra rudrapade yojanaṃ kriyate sā samayadīkșā. yatreśvarapade yojanam sā viśeșadīkșā. anayor ubhayor api nāsti śikhācchedah. yatra śivapade yojanam sā nirvāṇadīkṣā. yatra nirvānadīkṣapūrvakam sannyāsaḥ tatra tv asti śikhācchedah. 
tantric practice held a comparatively prominent role. It seems that the lokadharmini $\bar{i}$ ikssa $\bar{a}$ was created in this milieu in order to extend the benefits and services of the tantric repertoire to various groups within the brahmanical mainstream, in this way appealing to the ordinary lay worshipper, who was perhaps attracted by the magical and merit-enhancing aspects of the religion but did not want to commit to the ritual life of a tantric practitioner. This initial function aligns with a gradual process of professionalization within tantric Śaiva communities, bridging the gap between esoteric practitioners and the laity. In this matter they followed in the footsteps of the Atimārga, for epigraphical evidence attests to members of these Śaiva ascetic initiatory circles serving as religious officiants for lay practitioners from as early as the fourth century (Sanderson 2013). ${ }^{88}$ However, at the same time, the Sādhaka form of lokadharminī dīkșā is found only in the Svacchanda, Mrgendra, and the Tantrasadbhāva, suggesting that in the broader Śaiva tantric world-apart from Kashmir - its function was of marginal or no importance, a circumstance likely contributing to its disappearance from subsequent sources.

We have seen that in other sources using the lokadharmini category, this was reassigned to the sphere of the liberation-seeker. This allocation, in turn, may be correlated with two further developments. Firstly, increasing emphasis was given to the liberation-seeking aspect of the religion, a development that in the South culminates in the disappearance of the figure of the Śaiva Sādhaka, as Brunner $(1974,440)$ observes. Consequently, retention of an exoteric form of the enjoyment-seeker category may have gradually become obsolete. Secondly, we know that tantric Śaivism was successful in gradually adapting to the ritual needs of the brahmanical mainstream, even to the point of incorporating its practices within the tantric ritual repertoire, so that full initiation also became available to brahmanical householders, giving them unrestricted access to the religion. ${ }^{89}$ This development is reflected in the use of the category lokadharmiṇi dīkșā in the 12th-century Jñannaratnāvalī, where it is prescribed for precisely those householder initiates who had full access to the tantric repertoire but maintained their position and brahmanical ritual obligations in society (the lokadharma). Again, the need for a lokadharminī dìkșā, which made the bubhukșu aspect of the religion more accessible and may originally have been a catalyst for outreach, may thereby have become less meaningful. The increasingly large-scale inclusion of the brahmanical main-

88 See also Sanderson 2009 for the many ways in which tantric officiants created strong links with the laity, also by acting as officiants in the domain of royal and consecration rituals.

$89 \quad$ See Sanderson 1995 and 2009. 
stream from this time onwards is also visible in other areas of ritual, especially in South-Indian sources. Thus, for instance, we find the emergence of literature on penance rites regulating social interactions, such as the two works known as Prāyaścittasamuccaya by Hṛdayaśiva and Trilocana, respectively, the latter having been edited and translated by Sathyanarayanan (2015). In his introduction to this volume, Dominic Goodall draws attention to the socially allencompassing nature of the work, showing how its prescriptions include even women as part of the community, and how the focus shifts to public temple ritual. ${ }^{90}$ Goodall also points out another change within these tantric traditions, which we may find reflected in the history of the lokadharmini $\operatorname{li} k s s \bar{a}$, namely that along with these developments the goal of individual liberation gradually waned in importance. He observes also that the "colonization by the Śaiva Siddhānta of many large South Indian temples, and the dominance of Vedāntic non-dualism appear to have diminished the significance of ritual salvific dik $k s \bar{a} .{ }^{\prime 91}$ As the tradition's focus shifted from individual to public ritual life, it may be this waning importance of $d \bar{i} k s \bar{a}^{\prime} \mathrm{s}$ salvific function that has contributed to the confusion evident in Saiddhāntika manuals concerning how to categorize the lokadharminī and śivadharminī dīkșās. The dominant concern in allocating these initation types eventually became simply to differentiate the householder initiate from the ascetic, rather than to distinguish the spiritual goals attained through various initiations. This usage of the terminology is far removed from its original purpose: designating special types of tantric intiation for those seeking powers, access to higher cosmic realms, and, ultimately, liberation.

\section{Acknowledgements}

I am very grateful to Shaman Hatley for his careful reading and extremely helpful comments, suggestions and edits of the text.

90 In Sathyanarayanan $2015,15^{-63}$.

91 See Goodall's entry on dīkșā in Tāntrikābhidhānakośa, vol. III. For more on the influences on the development and formation of Śaiva Siddhānta theology from the 1oth century onwards, see Goodall 2006, in particular pp. 98-103. 


\section{References}

\section{Primary Sources}

Jayadrathayāmala, Șațka 1. NAK 3-358; NGM PP A 995/6-996/1. Palm-leaf, Pāla script. Jñānaratnāvalī of Jñānaśivācārya. Transcript of Re 1025/52 (57) copied by V. Rangasvami (GOML); photographed and transcribed by Dominic Goodall.

Tantrasadbhāva. E-text by Mark Dyczkowski, dated 1 August 2006, accessed through the Muktabodha Indological Research Institute website, based on the following manuscripts: NGMPP A188/22, śaivatantra 1533 (siglum k); NGMPP A44/1 (NAK 1363), śaivatantra (kh); NGMPP A44/2 (NAK 5-455), śaivatantra 185 (g).

Tantrāloka. Shāstrī, Mukund Rām, ed. Tantrāloka of Abhinavagupta, with the commentary (-viveka) of Rājānaka Jayaratha. Kashmir Series of Texts and Studies, no. 59. Bombay, 1938.

Netratantra. Madhusūdan Kaul Śāstrī, ed. Netratantra, with the Commentary (Netroddyota) of Rājānaka Kșemarāja. Kashmir Series of Texts and Studies, nos. 46, 59. Bombay: 1926 and 1939 .

Bṛhatkālottaratantra. NG MPP 4-131/vi Śaivatantra 127, Reel no. A43/1, Palm-leaf.

Mrgendra. Bhatt, N.R., ed. Mrgendra Kriyāpāda and Caryāpāda, with the commentary (-vṛtti) of Bhațta Nārāyaṇakaṇtha. Pondicherry: Institut français de Pondichéry, 1962.

Vimalāvatī of Vimalaśiva. NGMPP reel number A186/10. Eletronic text of the Muktabodha Indological Research Institute typed under the supervision of Mark. S.G. Dyczkowski.

Śaivasiddhāntaparibhāsāa of Śivāgrayogin. Oriental Research Institute Sanskrit Series, no. 9o, Madras: University of Madras, 1950. Eletronic text of the Muktabodha Indological Research Institute typed under the supervision of Mark. S.G. Dyczkowski.

Siddhāntaśekhara of Viśvanātha. Sītārāma Somayājin and Śiva Śrī Talakāḍu Āvamika Kṛṣnadīkṣita, eds. Ubhayavedānti Viśvanāthakṛtaḥ Siddhāntaśekharah. Manonmanīgranthamālā, no. 2o. Mysore: K. Sītārāma Somayājin, 1971.

Somaśambhupaddhati. See Brunner 1977.

Somaśambhupaddhativyākhyā of Trilocana. IFP T. no. 170.

Svacchandatantra. Madhusudan Kaul Shāstrī, ed. Svacchandatantra, with the Commentary (Svacchandoddyota) of Rājānaka Kșemarāja. Kashmir Series of Texts and Studies, no. 38. Bombay: 1923 .

\section{Secondary Sources}

Bhatt, N.R. 1962. Mrgendrāgama. Kriyāpāda et Caryāpāda. Avec le commentaire de Bhațta-Nārāyanakaṇța. Pondicherry: Institut Français de Pondichéry/ Ecole française d'Extrême-Orient. 
Brunner, Hélène. 1975. "Le sādhaka, un personnage oublié du Sivaïsme du Sud." Journal Asiatique 263: 411-416.

Brunner, Hélène, ed. and trans. 1977. Somaśambhupaddhati, Troisième Partie. Rituels occasionels dans la tradition śivaïte de l'Inde du Sud selon Somaśambhu II: dīkșā, abhișeka, vratoddhāra, antyești, śrāddha. Pondicherry: Institut Français de Pondichéry/École française d'Extrême-Orient.

Brunner, Hélène. 1985. Mrgendrāgama. Section des rites et section du comportement avec la vrtti de Bhațtanārāyaṇakaṇțha. Pondicherry: Institut Français de Pondichéry.

Goodall, Dominic. 1998. Bhațta Rāmakanțha's Commentary on the Kiranatantra. Volume I: chapters 1-6. Critical Edition and Annotated Translation. Pondicherry: Institut Français de Pondichéry/École française d'Extrême-Orient.

Goodall, Dominic. 200o. "Problems of Name and Lineage: Relationships between South Indian Authors of the Śaiva Siddhānta." Journal of the Royal Asiatic Society 10 (2): $205^{-216 .}$

Goodall, Dominic. 2004. The Parākhyatantra, a Scripture of the Saiva Siddhānta. A Critical Edition and Annotated Translation. Pondicherry: Institut Français de Pondichéry/École française d'Extrême-Orient.

Goodall, Dominic, Harunaga Isaacson, and Alexis Sanderson, et al. 2015. The Niśvāsatattvasamhitā. The Earliest Surviving Śaiva Tantra. Volume 1. A Critical Edition \& Annotated Translation of the Mūlasūtra, Uttarasūtra \& Nayasūtra. Pondicherry: Institut Français de Pondichéry/École française d'Extrême-Orient.

Kiss, Csaba. 2015. The Brahmayāmala Tantra or Picumata, Volume Two. The Religious Observances and Sexual Rituals of the Tantric Practitioner: chapters 3, 21 and 45. Pondicherry: Institut Français de Pondichéry/École française d'Extrême-Orient/ Universität Hamburg.

Mirnig, Nina. 2013. "Śaiva Siddhānta Śrāddha. Towards an evaluation of socio-religious landscape envisaged by pre-12th century sources." In Pușpikā. Tracing Ancient India Through Cults and Traditions, edited by Nina Mirnig, Péter-Dániel Szántó and Michael Williams, 283-301. Oxford: Oxbow Books.

Sanderson, Alexis. 1995. "Meaning in Tantric Ritual." In Essais sur le Rituel III: Colloque du Centenaire de la Section des Sciences religieuses de l'École Pratique des Hautes Études, edited by Anne-Marie Blondeau and Kristofer Schipper, 15-95. LouvainParis.

Sanderson, Alexis. 2001. "History through Textual Criticism in the Study of Śaivism, the Pañcarātra and the Buddhist Yoginītantras." In Les sources et le temps. Sources and Time. A colloquium. Pondicherry 11-13 January 1997, edited by François Grimal, 1-47. Pondicherry: Institut Français de Pondichéry/École française d' Extrême-Orient.

Sanderson, Alexis. 2004. "The Śaiva Religion Among the Khmers, Part I." Bulletin de l'École française d'Extrême-Orient 9o: 352-464. 
Sanderson, Alexis. 2005. "Religion and the State: Śaiva Officiants in the Territory of the King's Brahmanical Chaplain.” Indo-Iranian Journal 47: 229-230.

Sanderson, Alexis. 2006. "The Lākulas: New Evidence of a System Intermediate Between Pāñcārthika Pāśupatism and Āgamic Śaivism." Indian Philosophical Annual 24: $143-217$.

Sanderson, Alexis. 2007. "The Śaiva Exegesis of Kashmir." In Mélanges tantriques à la mémoire d'Hélène Brunner. Tantric Studies in Memory of Hélène Brunner, edited by Dominic Goodall and André Padoux, 231-442. Pondichéry: Institut Français de Pondichéry/École française d'Extrême-Orient.

Sanderson, Alexis. 2009. "The Śaiva Age-The Rise and Dominance of Śaivism in the Early Medieval Period." In The Genesis and Development of Tantrism, edited by Shingo Einoo, 41-349. Tokyo: Institute of Oriental Culture, University of Tokyo.

Sanderson, Alexis. 2014. “The Śaiva Literature." Journal of Indological Studies 24 \& 25: $1-113$.

Sathyanarayanan, R. 2015. With an introduction by Dominic Goodall. Śaiva Rites of Expiation. A First Edition and Translation of Trilocanaśiva's Twelfth-Century Prāyaścittasamuccaya (With a Transcription of Hrdayaśiva's Prāyaścittasamuccaya). Pondicherry: Institut Français de Pondichéry/École française d'Extrême-Orient.

Takashima, Jun. 1992. "Dīkṣā in the Tantrāloka." Institute for Advanced Studies on Asia (Tohyobunkakenkyusho kiyo) 119: 45-84.

Tāntrikābhidhānakośa. Dictionnaire des terms techniques de la littérature hindoue tantrique. Vol. III. Dominic Goodall et Marion Rastelli, eds. Beiträge zur Kultur- und Geistesgeschichte Asiens, no. 76. Vienna: Austrian Academy of Sciences Press, 2013. Vasudeva, Somdev. 2012. "Powers and Identities: Yoga Powers and the Tantric Śaiva Traditions." In Yoga Powers: Extraordinary Capacities Attained Through Meditation and Concentration, edited by Knut A. Jacobson, 265-302. Leiden: Brill.

Watson, Alex, Dominic Goodall and S.L.P. Anjaneya Sarma. 2013. An Enquiry into the Nature of Liberation. Bhaț̣a Rāmakaṇtha's Paramokṣanirāsakārikāvṛtti, a Commentary on Sadyojyotih's Refutation of Twenty Conceptions of the Liberated State (mokșa). Pondicherry: Institut Français de Pondichéry/École française d'Extrême-Orient. 